\title{
The relation between public assistance and self-employment in census tracts: a long-term perspective
}

\author{
Pankaj C. Patel ${ }^{1}\left(\mathbb{D} \cdot\right.$ Cornelius A. Rietveld $^{2} \mathbb{D} \cdot$ Jack I. Richter $^{3} \mathbb{D}$
}

Accepted: 21 August 2021 / Published online: 15 October 2021

(C) The Author(s) 2021

\begin{abstract}
We present evidence on the long-term relationship between the breadth (the proportion of households) and depth (the amount per household) of public assistance and the prevalence of self-employment in US neighbourhoods. The analysis of decennial data of 71,437 census tracts over four decades (1970 to 2000) shows that the poverty ratio lowers self-employment, and that breadth (but not depth) of public assistance mitigates the negative relationship between the poverty ratio and self-employment. The results are robust to alternate model specifications and are informative about the distributional effects of welfare spendings.
\end{abstract}

Keywords Census tracts $\cdot$ Poverty $\cdot$ Public assistance $\cdot$ Self-employment $\cdot$ Welfare programs

JEL codes H5 $\cdot \mathrm{L} 26 \cdot \mathrm{R} 13$

Cornelius A. Rietveld

nrietveld@ese.eur.nl

Pankaj C. Patel

pankaj.patel@villanova.edu

Jack I. Richter

id19b@fsu.edu

1 Villanova School of Business, Villanova University, 800 E. Lancaster Avenue, Villanova, PA 19085, USA

2 Erasmus School of Economics, Erasmus University Rotterdam, Burgemeester Oudlaan 50, 3062 PA Rotterdam, The Netherlands

3 Present Address: College of Business, Florida State University, 821 Academic Way, Tallahassee, FL 32306, USA 


\section{Introduction}

Although much of poverty alleviation research focusses on developing countries, poverty is also a concern in developed countries. According to the Federal Safety Net in the US, 44 million or one in seven citizens live in poverty, ${ }^{1}$ and about 10 percent of the US citizens are permanently poor and welfare-dependent (Laird et al. 2018; Morello 2010; Morris et al. 2018). Similarly, in the UK and the European Union, the relative poverty levels are in the mid-teen percentages (Michálek and Výboštok 2019). In efforts to alleviate relative poverty (i.e., "much less"), as distinct from absolute poverty (i.e., "not enough") (Notten and De Neubourg 2011), policy makers in developed countries invest in a variety of safety-net programs. Policymakers face a vexing problem of allocating and managing public assistance to provide the much needed safety net to the economically vulnerable, but to also impel selfsustainability in such economically disadvantaged locales. As a result, encouragement of self-employment in disadvantaged neighbourhoods is of growing interest among policymakers (Sutter et al. 2019; Morris 2021).

Most research on the influence of public assistance focuses on the contemporaneous associations of partaking in welfare programs. Public assistance programs may contribute the necessary safety net for improving investments in human capital and for supporting families that in turn may improve long-term labour market outcomes (Fryer 2017; Moffitt 1999; Sandberg 2016). Receipts of public assistance may influence the formation of the human capital of parents and children, increase local consumption levels, and have a long-term community influence in promoting, supporting, and engaging in self-employment. However, research over decades on the value of public assistance and vocational outcomes has shown that most of the individuals facing serious economic disadvantages have limited training and skills, and social programs seem to play a limited role in improving their economic conditions (Hamilton 2016). According to some critics, public assistance may lead to excess dependence on such programs and lower incentives to engage in self-employment. These competing narratives on the value of public assistance for promoting long-term economic outcomes such as self-employment call for a closer examination.

Through the theoretical lenses of liability of poorness (Morris et al. 2020a) and regional development (Capello and Nijkamp 2019; Fischer and Nijkamp 2019), in this study, we aim to counter this gap in the literature by focusing on the longterm relationship between public assistance payments and self-employment in census tracts. ${ }^{2}$ The long-term perspective we adopt is essential because public assistance may not relieve the short-term economic and non-economic binding constraints. With the goal of public assistance programs to improve communities

\footnotetext{
1 For 2020, the federal government defined the poverty level as an annual income of $\$ 26,200$ or lower for a family of four or $\$ 12,760$ or lower for a single individual.

2 A census tract is defined as "a small, relatively permanent statistical subdivision of a county delineated by a local committee of census data users for the purpose of presenting data". Census tracts average about 4,000 inhabitants, and are designed to be relatively homogeneous units with respect to population characteristics, economic status, and living conditions at the time of establishment (US Census 2014). See Appendix 2 Fig. 2 for an example of a census tract.
} 
and long-term economic outcomes, understanding the role of such programs in improving self-employment on aggregate may be central to further informing the efficacy of such programs. Specifically, we assess the influence of the poverty ratio on self-employment ${ }^{3}$ in the next decade and whether the proportion of households on public assistance (breadth) or public assistance per capita (depth) moderates this relationship.

We analyse decennial data over four decades (1970 to 2000) to estimate the longterm relationships between public assistance policies and self-employment. Following Neumark et al. (2019), we use in our study the long-term longitudinal data available from the Neighborhood Change Database (NCDB) provided by GeoLytics (GeoLytics 2016). We are drawing on aggregated data on the census tract level because long-term individual-level data are not available in the US (Neumark et al. 2019). The historic tax returns data from the 1970s and 1980s are not fully digitized and recent works on generational mobility also draw on confidential tax return data from the 1980s. Moreover, those receiving public assistance may not have taxable income and because of their limited assets and investments using tax return data may be less useful for our purpose. The Survey of Income and Program Participation (SIPP) from 1984 to 2014 covers recipients of government programs, but it provides information on a four year rotating panel of individuals with the lowest granularity at the state-level. Although the analysis of long-term individual-level data would have been most ideal to answer our research question, only the NCDB data provide us the necessary geographic granularity and the time span to answer our research question.

Our findings show that the poverty ratio of census tracts in the current decade is negatively associated with the percentage of households with self-employment in the next decade. The breadth of public assistance (proportion of households on public assistance) partially mitigates this relationship. However, the depth of public assistance (higher per capita public assistance) does not seem to be meaningfully associated with self-employment in the next decade. Though causal inferences are challenging to derive in the current context, a variety of robustness checks (including a model which controls for the geographical proximity of census tracts and a placebo test) support these inferences. Hence, the results provide suggestive evidence that higher poverty ratios may lower self-employment, and that increasing the breadth rather than the depth of public assistance in economically disadvantaged census tracts may result in higher self-employment rates.

These findings are informative for research and policy debates in two main ways. First, with our research question that reverses the earlier focus in the literature on whether self-employment lowers poverty, our study is informative for the long-running policy debate on whether public assistance is successful in improving

\footnotetext{
3 In our study, we focus on self-employment. Self-employment represents a wide range of activities conducted by individuals without employers (e.g., freelancers, contractors, professional services, and business owners), whereas entrepreneurs typically engage in high-growth businesses (Henrekson and Sanandaji 2020). Therefore, the distinction between self-employment and entrepreneurship is important to make (Kwon and Sohn 2021; Van Stel and Van der Zwan 2020).
} 
autonomy and self-reliance. Our longitudinal analysis across census tracts exploits variation in available safety nets to pursue self-employment. The income risk associated with self-employment is lower when public assistance may be available, and a large amount of research has focused on the role of enclaves, economic and social vibrancy of the neighbourhood, and the need for "keeping dollars in the community" (Andersson and Larsson 2016; Gittell and Thompson 1999; Stough 2016). Public assistance aggregating at the neighbourhood level could be a gathering force that builds over time to promote self-employment. However, economic self-efficiency may also deteriorate in the long term because successful self-employment is also rooted in the economic health of the neighbourhood (Braymen and Neymotin 2014). Our findings are informative for the type of policy (breadth rather than depth of public assistance) most suitable for stimulating self-employment.

Second, with increasing concerns for intergenerational mobility in the US, it is important to be aware of the long-term impact of welfare programs on improving socio-economic mobility through self-employment. If the primary goal of providing safety nets is the upliftment of the economically disadvantaged, then extending prior works on the role of such programs (Neumark et al. 2019; Neumark and Young 2019) and the broader literature on distributional (Bitler et al. 2006; Friedlander and Robins 1997) and employment (Mariani et al. 2019; Rodriguez 2001) effects need to be further informed through the dimension of self-employment. Grogger (2003) found that welfare programs improved employment, however, whether it drives selfemployment in the longer term remains less understood (Olds 2014). The efficacy of public assistance programs aggregates over time and may have spillover effects in the locale. By drawing on the aggregate public assistance payments at the census tract level in the period 1970-2000 and by accounting for the potential spillovers from these gains, our study contributes to our understanding of the long-term association between the breadth and depth of public assistance and the prevalence of self-employment.

The remainder of this study is organized as follows. In Section 2, we review the literature and derive our hypotheses. In Section 3, we describe the data and methodology. The empirical results are presented in Section 4. Finally, in Section 5, we discuss our findings and provide conclusions.

\section{Theoretical development and hypotheses}

In this section, we review the literature on the relationship between poverty and selfemployment to hypothesize the directionality of the association between the poverty ratio and the proportion of households with self-employment in a census tract. In doing so, we devote particular attention to the motivations (i.e., opportunity vs. necessity motives) individuals in poorer neighbourhoods may have to engage in selfemployment. Subsequently, we use evidence about the impact of public assistance programs to formulate expectations about how the breadth and depth of public assistance may moderate the relationship between the poverty ratio and the proportion of households with self-employment in a census tract. 


\subsection{Self-employment in poor neighbourhoods}

As discussed by Iftikhar et al. (2020), Chinitz (1961) challenges that "the supply schedule of entrepreneurship is identical at all locations" because "the entrepreneurial supply curve is also a function of certain traditions and elements of the social structure which are heavily influenced by the character of the area's historic specializations". In our study, we focus on the regional character of a neighbourhood through the lens of poverty. Importantly, in socio-economically marginalized neighbourhoods exposure to formal economic activities is relatively low and individuals are more likely to operate outside state regulations to avoid taxes and oversight (Gómez et al. 2020). Informally, self-employed individuals may for example engage in casual jobs, such as contracting, day-care, and cab driving (Chen 2005). Williams and Windebank (2002) studying affluent and deprived neighbourhoods in London find a significant amount of informal pay work and contracting among the working poor. In more recent work, Williams (2014) provides an overview of informal economic activities in European Union member countries and surmises that even in these developed economies, self-employment falls on an informal and formal continuum: "informal workers also sometimes operate as social actors and undertake own-account informal work for kin, neighbours, friends, and acquaintances for reasons other than financial gain, including redistributive and familial and community solidarity rationales" (p. 738). The informal economy is also prevalent in poorer areas in the US (Leonard 1998). Therefore, it is important to appreciate that especially in poor neighbourhoods self-employment operates on a formal-informal continuum.

The relationship between poverty and self-employment can be understood through the recent conceptualization of the liability of poorness by Morris et al. (2020a). The liability of poorness concerns literacy gaps, scarcity mindset, intense non-business pressures, and lack of financial slack. Literacy gaps lower the overall human capital necessary to identify opportunities, collate resources to organize a firm, and managing day-to-day business operations. Limited functional, financial, economic, or business literacy may add significant hindrances to the communitylevel business formation processes. Scarcity mindset refers to a short-term orientation that limits planning ability and increases reactiveness (instead of proactiveness) to business problems. Additional community-related challenges stemming from crime, health, and general malaise increase personal pressures that may take away attention from focusing on self-employment. Finally, the lack of financial slack stemming from lower profitable businesses, credit rationing from lenders, and limited savings, may further lower the prospects of self-employment.

There is a large literature indeed highlighting that the general malaise in poor neighbourhoods may hinder self-employment, and several arguments in this literature relate to the liability of poorness. Based on the income shortfall perspective and the relative view of poverty (Cumming et al. 2020), the motivation for self-employment may be limited in poorer neighbourhoods. The local environment plays an important role in shaping entrepreneurial activity (Andersson and Larsson 2016; de Beer 2018; Sutton 2010). Social, market and institutional factors are deeply rooted in the local community and form the background which primes entrepreneurial 
activity in an area. The impetus for entrepreneurial activity is deeply embedded in the local environment (Sutton 2010). A high poverty ratio limits the development of and usage of labour, restricts the availability of capital, and provides limited socioeconomic support, culture, and institutions that foster the degree of self-employment in an area (Oreopoulos 2003). A higher poverty ratio in an area may also restrict the necessary accumulation of human, economic, and social capital to effectively pursue self-employment. For example, education constitutes one of the basic building blocks for developing entrepreneurial human capital (Martin et al. 2013). However, poorer areas have relatively weak educational infrastructures, which limits the accumulation of human capital. Thus, neighbourhoods with a higher poverty ratio may not provide the necessary infrastructure to support self-employment efforts. A higher poverty ratio promotes the general social malaise that may further hinder the community and social support necessary to start a business (Berner et al. 2012; Devereux 2002; Kleinhans et al. 2017; Olsen 2010; Small and McDermott 2006; Venugopal et al. 2015). Fewer role models, high crime rates, limited ability to keep the money circulating in the local economy, and the focus on meeting basic needs are some of the hindrances that may lead to the expectation of a negative relationship between the poverty ratio and self-employment in an area.

A higher poverty ratio is also indicative of the systemic inefficiencies and imperfections in local institutions and infrastructure. Broadly, self-employment activity in high poverty areas is limited by lower legitimacy and by the limited available socio-economic platforms to develop connections and networks for partnerships and financing (Wilson and Wilson 2017). The less-developed industry and markets in higher poverty areas lower the quality of available opportunities (Hayek 1945). High poverty conditions also limit the level of aspirations (Dalton et al. 2016). Wellknown conceptualizations such as poverty traps highlight the set of hindrances faced by individuals in developing aspirations for self-actualization (Chivers 2017). The collective resources of an area with a high poverty ratio may therefore not facilitate the mobilization of necessary resources and skills to adapt to changing conditions, nor provide the necessary psychological and socio-emotional resources to prime entrepreneurial activity (Schreiner 1999). Morris et al. (2020b) also highlight the exclusion of the poor from entrepreneurial ecosystems, because policymakers generally do not consider poor neighbourhoods as hotbeds of high-growth entrepreneurship.

Nevertheless, there are also reasons why regional poverty may be positively associated with self-employment. First, based on the social aspiration theory (Ray 2006) and the social comparison theory (Crettaz and Suter 2013), poverty could prime individuals to change their conditions through self-employment. Social aspiration theory in the context of poverty states that aspirations are shaped by the surroundings and although aspirations can inspire, excess aspirations can also lead to frustrations and resentments (Genicot and Ray 2020). In adapting their aspirations, through social comparison, poor individuals "compare themselves with others who are in the same precarious situation or even worse off and, as a result, lower their expectations and adapt their aspirations and preferences to their material and financial constraints" to perhaps pursue self-employment (Crettaz and Suter 2013, p. 139). Studies about 
entrepreneurship enclaves have shown that when outside job opportunities are lacking, individuals are more likely to identify local opportunities to meet local needs. As such, although self-employment is often informal in poor neighbourhoods (e.g., providing unregistered child care services, beauty salons, handyman services), self-employment may provide a route to make a living for oneself (Estrin and Mickiewicz 2012; Levitte 2004). Among the available possibilities to pursue aspirations or to close poverty gaps, self-employment could be a viable path to self-sufficiency. Moreover, as a route for autonomy and self-reliance, self-employment may help individuals to find selffulfillment by identifying and exploiting local opportunities.

Moreover, based on the economic assimilation hypothesis (Stolzenberg and Tienda 1997), those in the high poverty neighbourhoods may see self-employment not only as a mode to make a living but also as a mode for upward socio-economic mobility. Socio-economic disadvantages could impel residents to actively create, develop, and exploit potential business opportunities to improve the microcosmos of the local economy. The co-created economic, human, and social capital in the neighbourhood may foster the ecology of local business opportunities that address local economic and social needs. Poorer living circumstances may also create a local identity that may be beneficial for developing the local entrepreneurial infrastructure. The enclave entrepreneurship literature (Portes and Manning 2005) argues that the spatial location and reliance on similar others is important for building shared economic prosperity. The spatially bounded nature of a neighbourhood may create a shared identity and human capital that is perhaps more valuable in the neighbourhood itself (e.g., social relations and co-dependence) than outside it. Even more, negative poverty experiences may be a resource in entrepreneurship as reflected by "toughness, hustle, and the abilities to bounce back from setbacks, adapt to new challenges and find clever ways around resource constraints" (Morris and Tucker 2021, p. 15). Thus, the shared social networks and interdependencies could somewhat foster self-employment in poorer neighbourhoods.

The above arguments highlight two important points. On the one hand, we have the general malaise, exclusion, and poorer infrastructure that are characteristic features of the liability of poorness and that lead to a negative relationship between poverty and self-employment in a neighbourhood. On the other hand, self-employment may be a mode to move out of poverty. However, the literature shows that this type of self-employment often relates to informal activities. We do not discount the value of poverty as a catalyst to pursuing entrepreneurial dreams, however, at the neighbourhood level, the overall socio-economic disadvantages are more likely to tamp self-employment. Therefore, we hypothesize:

Hypothesis 1 The poverty ratio is negatively associated with the proportion of households with self-employment in a neighbourhood.

\subsection{Public assistance and the relationship between poverty and self-employment}

In socially disadvantaged neighbourhoods, public assistance could be the necessary starting point to prime self-employment behaviour by providing the economic base 
to sustain self-employment efforts. Aggregate levels of public assistance could be effective in building social, cultural, and economic relations within a community to develop conditions supporting self-employment. The breadth and depth of public assistance may foster the economic self-sufficiency necessary to push self-employment in disadvantaged neighbourhoods. In the Appendix 1, we provide a brief historical overview of safety net programs in the US.

States distribute grants to recipients using their own formula, and recipients of public assistance typically enroll in multiple programs. Therefore, it is difficult to track the impact of individual programs on poverty reduction. For example, in 2014, for Temporary Assistance for Needy Families (TANF), a states' asset threshold ranged from $\$ 1,000$ to $\$ 10,000$ across 27 states. As a result, researchers have focused on the influence of aggregate transfers on poverty alleviation. The benefits of these programs on poverty alleviation cannot be discounted. In 2012, 19.1 million children received meals under the school breakfast and lunch program, Medicaid and the Children's Health Insurance Program (CHIP) covered 36.7 million recipients, and housing programs assisted 3.3 million households. The child support program created in 2012 increased assistance to 17.2 million children and the Earned Income Tax Credit (EITC) raised the family income of 28.2 million tax filers (Chaudry et al. 2016). Safety nets cut the poverty rate from $28.7 \%$ in the 1960 s to 16 percent in 2012, translating into 40 million people lifted out of poverty.

A series of studies reviewing the benefits of welfare to human capital and health benefits have highlighted its benefits for both adults and children (Hahn et al. 2019). Countering the benefits of public assistance programs, in their review of the literature about disincentives to work, Ben-Shalom et al. (2012) found that public assistance programs had limited, if any, influence on low-income populations. Hence, although the decline in poverty driven by public assistance has broader theoretical support, there is limited evidence on whether public assistance programs improve the propensity for self-employment. However, for taking part in some of the programs, a work requirement is a condition. For example, TANF receipts are conditional on work effort and the EITC rewards are coupled with low-wage work. Research has found that EITC expansions are associated with a higher entry in the labour force (Eissa and Hoynes 2006) and also with an increase in labour force participation by secondary earners in the households (Dickert et al. 1995; Eissa and Hoynes 2004, 2006; Ellwood 2000). Therefore, there is some evidence that public assistance programs do impel individuals and households to enter labour markets, and by extension that these programs may drive entry into self-employment.

\subsection{The moderating role of the breadth of public assistance in the relationship between poverty and self-employment}

The breadth of public assistance refers to the proportion of households receiving public assistance. With increasing breadth, local resources, and social structures necessary for self-employment may improve. First, the wider safety net may provide a long-term basis to improve the necessary stocks of entrepreneurial resources in a neighbourhood. The breadth of public assistance may provide means to scale 
the hurdles of local institutional voids, lower transaction costs in accessing selfemployment resources, and lower the risk of discrimination in credit markets, thus improving the chances of socio-economic integration. Greater breadth could also empower otherwise marginalized communities to improve intentions and behaviours toward entrepreneurial undertakings and promote the necessary changes in social and institutional mechanisms which may improve the conditions for self-employment. Second, based on the theory of planned behaviour (cf. Rhodes et al. 2006), the wider safety net in the neighbourhood could improve entrepreneurial intentions and behaviours over time. Relatedly, an increased proportion of households on public assistance improves participation in entrepreneurial activity (Ghani et al. 2014; Scott et al. 2012) by lowering the "socially constructed realities of the poor, thus implicitly embracing other epistemological and ontological stances such as critical realism [to improve the] social and institutional realities of the poor, and the ways entrepreneurship is involved in change." (Sutter et al. 2019, page 201). Third, related to neighbourhood-level improvements, an increasing proportion of households with public assistance improves the lived experiences of those in poverty (Datta and Gailey 2012). Therefore, greater breadth is also associated with the reform perspective (Karlsson and Dahlberg 2003) by improving the social context promoting entrepreneurship (Ghani et al. 2014; Mair et al. 2012). Through the remediation perspective lens (Sutter et al. 2019), a greater proportion of households on public assistance may help provide the necessary critical resources and a safety net to communally prime the intentions and behaviours to improve economic conditions and also engagement in self-employment.

Overall, we expect that a greater proportion of households on public assistance (breadth) provides both the reform and remediation necessary to mitigate the negative relationship between poverty and self-employment in economically disadvantaged areas. Thus, our second hypothesis is:

Hypothesis 2 The negative relationship between the poverty ratio and the proportion of households with self-employed in a neighbourhood is weaker in neighbourhoods with a higher proportion of households on public assistance.

\subsection{The moderating role of the depth of public assistance in the relationship between poverty and self-employment}

The depth of public assistance refers to the amount of public assistance received by households. Koellinger and Minniti (2009) find that higher unemployment benefits, a form of public assistance, could crowd out nascent entrepreneurial activity by making the opportunity costs for engagement in self-employment higher. Still, by taking into account a broader range of public assistance programs, public assistance may also partially alleviate the insecurities around the engagement in self-employment. The depth of public assistance is particularly beneficial to households in undertaking self-employment as a hedge against income instability and fluctuations in income and earnings (Ziliak et al. 2011). When income is unstable, individuals may avoid self-employment altogether 
(Attanasio and Weber 2010) as they may lack the precautionary income support. Thus, a greater depth of public assistance may provide the necessary security by increasing income stability. Specifically, public assistance programs may provide the necessary insurance against basic needs such as food, housing, and medical expenses. Hence, deeper public assistance can provide the necessary insurance to help households consider self-employment and associated human capital investments (Gennetian et al. 2015; Hill et al. 2013), especially in areas of higher poverty ratio where these concerns are significant. This relatively general argument can be split out into three sub-arguments.

First, public assistance, as a mode of poverty alleviation, strengthens reform and remediation benefits necessary to assist socio-economically disadvantaged individuals to undertake self-employment (Friedlander and Robins 1997). As proposed in a comprehensive review of the literature about entrepreneurship and poverty by Sutter et al. (2019), the remediation perspective states that poverty is a result of a lack of resource provision (Sutter et al. 2019). Although this perspective focuses on the provision of resources by external partners to improve opportunity identification, exploitation, and growth at the neighbourhood level, the depth of public assistance could help to provide the necessary social, cultural and economic fortification to promote entrepreneurial intention. The key hurdle to the entrepreneurial undertaking is economic insecurity among the working poor (Buera 2008). Greater depth promotes skill gathering and education to acquire the necessary skills and resources and provides the added security of a stronger safety net that may improve attitudes and behaviour towards self-employment. Given that the greatest hurdle among the poor is access to capital and credit (Kobeissi 2010; Morduch 2000), greater depth may allow for the necessary buffers to improve credit scores and asset accumulation necessary for self-employment.

Second, poorer neighbourhoods are not embedded in a system of higher local economic efficiency. That is, the production function in the neighbourhoods is not based on the classical set of labour, capital, resources, and knowledge-intensive skills but on complex social, economic, cultural, and local institutional tapestry. The depth of public assistance could be the starting point of laying the groundwork to prime such systems and providing the necessary slack and security. The deeper safety net improves the texture of the structure and content of relationships in the community as more resources could prime collective shaping and exploitation of opportunities (Chakravarty and Shahriar 2015; Field et al. 2013). The depth of public assistance may also improve the strength of the safety net and thus could also drive the aggregation and synthesis of social and economic resources that foster self-employment in the long-term. As the remediation perspective assumes that increased availability of resources lowers resource scarcity and paves the way for new opportunities, greater depth may not only provide the necessary security but may also help to close deeper institutional and resource voids that could curtail self-employment intentions and behaviours.

Third, the infusion of deeper public assistance funding could also increase local consumption. Increased local consumption could have a multiplier effect on the local economy (Hanson 2010), that in turn, could increase entrepreneurial opportunities. In economically disadvantaged neighbourhoods, 
keeping money in the neighbourhood is essential to sustain the local economy. As such, increased consumption could provide entrepreneurial opportunities and strengthen the long-term economic sustainability of the neighbourhoods. Greater depth further increases the multiplier effect of keeping 'dollars in the local economy.'

Therefore, overall, we expect that a larger amount of public assistance per household (depth) improves the necessary safety net such that it may mitigate the negative relationship between poverty and self-employment in economically disadvantaged areas. Therefore, our third hypothesis is as follows:

Hypothesis 3 The negative relationship between the poverty ratio and the proportion of households with self-employed in a neighbourhood is weaker in neighbourhoods with a higher amount of public assistance per household.

\section{Data and methodology}

\subsection{Sample}

Our data are derived from the Neighborhood Change Database (NCDB) as provided by Geolytics. The dataset was created in collaboration with the Urban Institute and partly funded by the Rockefeller Foundation. The purpose of the dataset is to provide a harmonized micro-region level data to policymakers and researchers. The harmonization across census tracts is based on normalization to 2010 tract boundaries, by weighting the data from each decade to 2010 boundaries. This harmonization allows the comparison of census tracts over the past decades.

The data constitute harmonized census tract level aggregates. ${ }^{4}$ The data focus on earnings, employment, poverty, and public assistance. Besides, the dataset includes rich information about census tract-level changes over time, including population, demographic, and socio-economic characteristics. Specifically, the NCDB includes data from the 1970, 1980, 1990, and 2000 US Census, and from the five-year rollups of the 2006-2010 American Community Survey (ACS, referred to as the 2010 wave). However, the self-employment prevalence is not available in the ACS data, therefore the analysis is restricted to the first four decades (1970 to 2000). According to Neumark et al. (2019), "NCDB remains the best public data set" to assess the influence of granular local changes over time and even the 1970 wave is "reasonably representative of 1970 national averages" (p. 5-6). A particular advantage of the dataset is that it covers four decades, making that we can test for long-term associations using 10-year lags.

\footnotetext{
${ }^{4}$ For a detailed description of the collation of variables from each census, we refer to the Data Dictionary (Appendix E, in the GeoLytics documentation, available at https:/www.geolytics.com/USCen sus,Neighborhood-Change-Database-1970-2000,Data,Variables,Products.asp). For ready reference, we provide the associated variable stem for each variable.
} 


\subsection{Measures}

\subsubsection{Dependent variable - the proportion of households with self-employment $(t+$ decade)}

The outcome variable is the proportion of households with at least one self-employed person at the end of the next decade. The measure in NCDB (AVEMERyD) is based on the proportion of households reporting income from self-employment.

\subsubsection{Predictor variable-poverty ratio $(t)$}

The poverty ratio is the proportion of total persons below the poverty level last year (POVRATy).

\subsubsection{Moderator variable 1-the proportion of households on public assistance $(t)$}

Our first moderator variable is the proportion of households on public assistance ("Households with public assistance income (incl. SSI) last year"; AVPBLAyD). This measure covers a range of public assistance programs such as the Supplemental Security Income (SSI), Supplemental Nutrition Assistance Program (SNAP), Special Supplemental Nutrition Program for Women, Infants, and Children (WIC), Temporary Assistance for Needy Families (TANF) including pass-through Child Support General Assistance (GA), Earned Income Tax Credit (EITC), and Housing Assistance (HA).

\subsubsection{Moderator variable 2-logarithm of the average amount of public assistance per household $(t)$}

Our second moderator variable is the amount of public assistance received per household per year ("Average household public assistance income (incl. SSI) last year (\$)"; AVPBLAy). The variable is based on the annual amount as reported in the Census. Because of its skewness, we apply a logarithmic transformation to the variable.

\subsubsection{Controls $(t)$}

A variety of local factors could, directly and indirectly, influence the absorption and fruition of public assistance. Census tracts with a larger population may face greater direct and indirect social, cultural, and institutional frictions in realizing benefits from public assistance (Lobao and Hooks 2003). However, larger census tracts may also provide the necessary opportunities and the economic breadth to provide the necessary support system to pursue self-employment (Freire-Gibb and Nielsen 2014). Males are also more likely to engage in self-employment (Marlow 1997). Moreover, a greater presence of males in the labour force of a census tract might also increase the likelihood of higher self-employment prevalence. Therefore, we control for the logarithm of the total population and the logarithm of males in the labour force. 
Furthermore, to control for the overall economic health of a census tract and because of the relationship between the poverty ratio and average local income (Caldwell et al. 1998), we control for the logarithm of average household income. The efficacy of public assistance could also be conditional on the migration patterns in the state (Anjomani 2002). Data on migration across census tracts are not available, but we can control for the proportion of individuals staying in the state for the past five years. Based on Baum-Snow et al. (2019), some of the key proxies for the availability and sustainability of jobs are the available transportation opportunities. We, therefore, control for the logarithm of the population taking public transport to work, the logarithm of the population taking the automobile to work, and the proportion of the population traveling in the same metro for work. Finally, to control for unique decade and census tract characteristics, we include dummies for the decades as well as for the census tracts.

\subsection{Empirical specification}

Our main analysis is a fixed-effect regression with the proportion of households with self-employed in the next decade as the dependent variable. Because of the large number of fixed effects, we use the Stata 16.1 routine reghdfe. Our main independent variable is the poverty ratio in the census tract, which we interact with the proportion of households on public assistance (breadth) and the logarithm of the average amount of public assistance per household (depth).

\section{Results}

\subsection{Main results}

Table 1 provides the descriptive statistics of our analysis sample. After casewise deletion of observations with missing values, our sample comprises 273,570 census tract-decade observations from 71,437 distinct census tracts. The proportion of households reporting self-employment in the sample is $12.3 \%$, fairly consistent with the prevalence rate of self-employment in the population. Also in line with the national estimates in recent decades, the mean poverty ratio was $11.10 \% .^{5}$ In our sample, about $6.50 \%$ of the households received some form of public assistance. The average public assistance received was $\$ 1,143.67$. Table 2 presents the correlation table. The proportion of households with self-employment in the next decade is negatively associated with the poverty ratio $(r=-0.255, p<0.01)$, the proportion

\footnotetext{
5 When we focus on the development of poor census tracts over time (in the subsample of census tracts for which we have information in all four decades), we find that from the $10.7 \%$ census tracts that are poor in 1970 (defined as having a poverty ratio>0.2; a "poverty area" according to the U.S. Census Bureau) most have remained poor (7.0\%). However, a considerable proportion has become rich by 2000 (3.7\%). Conversely, from the $89.3 \%$ rich census tracts in $1970,76.8 \%$ are still rich in 2000 but $12.5 \%$ have become poor.
} 
Table 1 Descriptive statistics analysis sample $\left(N_{\text {census tract } \times \text { decade }}=273,570, N_{\text {census tract }}=71,437\right)$

\begin{tabular}{llll}
\hline & & Mean & S.D \\
\hline 1 & Proportion of households with self-employment in the next decade & 0.122 & 0.071 \\
2 & Poverty ratio & 0.110 & 0.109 \\
3 & Proportion of households on public assistance (Breadth) & 0.065 & 0.075 \\
4 & Logarithm of the average amount of public assistance per household (Depth) & 7.067 & 2.568 \\
5 & Logarithm of the total population & 7.191 & 2.381 \\
6 & Logarithm of males in the labour force & 5.897 & 2.025 \\
7 & Logarithm of average income per family & 9.404 & 3.003 \\
8 & Proportion of the population staying in the state in the past five years & 0.777 & 0.281 \\
9 & Logarithm of the population taking public transport to work & 2.644 & 2.083 \\
10 & Logarithm of the population taking automobile to work & 6.240 & 2.149 \\
11 & Proportion of the population traveling in the same metro area for work & 0.678 & 0.413 \\
\hline
\end{tabular}

S.D. $=$ Standard Deviation. Descriptive statistics for the decade and census tract dummies are available upon request from the authors

of households on public assistance $(r=-0.266, p<0.01)$, and the logarithm of the average amount of public assistance received $(r=-0.115, p<0.01)$. Not surprisingly, the poverty ratio is positively associated with the proportion of households receiving public assistance $(r=0.794, p<0.01)$, and the amount of public assistance received $(r=0.299, p<0.01)$.

Table 3 present the main empirical results. Column 1 shows that the poverty ratio is negatively associated with the proportion of households reporting self-employment in the next decade. The regression coefficient suggests that a one percent increase in the poverty ratio is associated with a decline of $0.11 \%$ in the proportion of households reporting self-employment in the next decade. This result is in line with Hypothesis 1 . The amendment of the proportion of households on public assistance (breadth) and the logarithm of the average amount of public assistance per household (depth) in Column 2, renders the coefficient for the poverty ratio a little smaller but it remains negative and statistically significant.

Interestingly, both breadth and depth are negatively associated with the proportion of households reporting self-employment in the next decade in Column 2. Census tracts are relatively homogeneous regarding population characteristics, economic status, and living conditions (US Census Bureau 2020), and these negative coefficients seem to reflect that economic conditions in poorer census tracts keep deteriorating over time. Nevertheless, the positive and significant interaction term in Column 3 shows that the proportion of households on public assistance tempers the association between the poverty ratio and household selfemployment in the next decade. This result is in line with Hypothesis 2. Column 4 in Table 3 indicates that the interaction between the poverty ratio and depth of public assistance is negatively associated with household self-employment in the next decade. This result goes against Hypothesis 3, in which a positive interaction was expected. Column 5 shows that the joint inclusion of the interaction terms has a small influence on the estimated coefficients. The coefficient for the breadth 


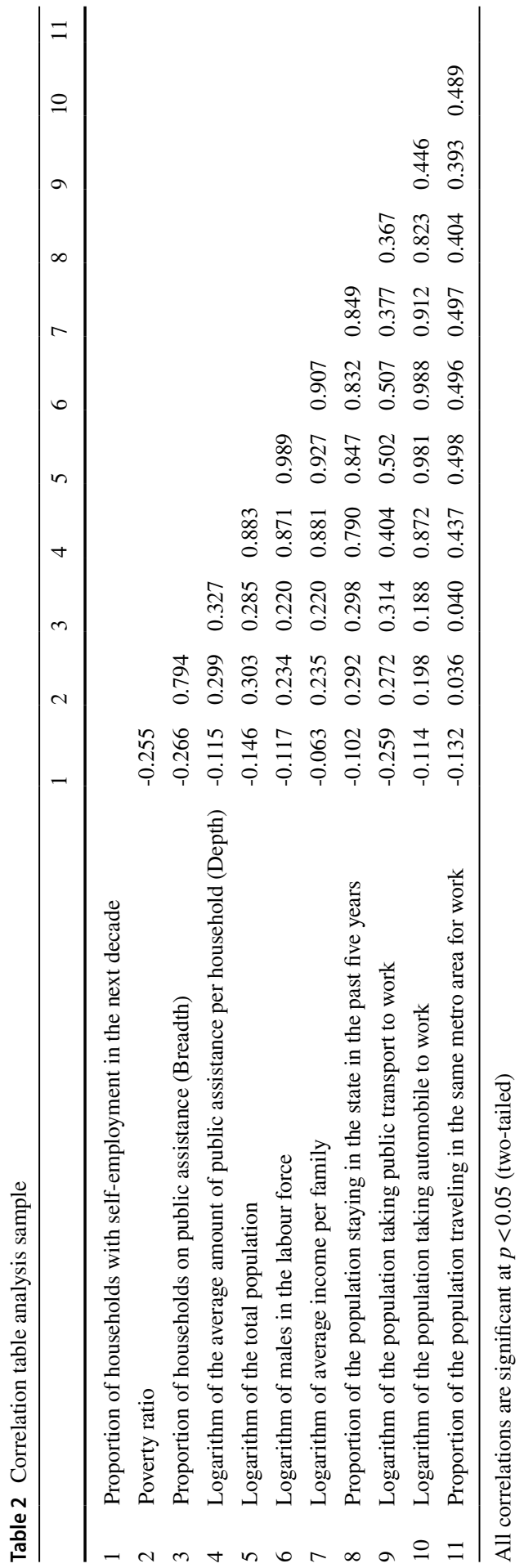




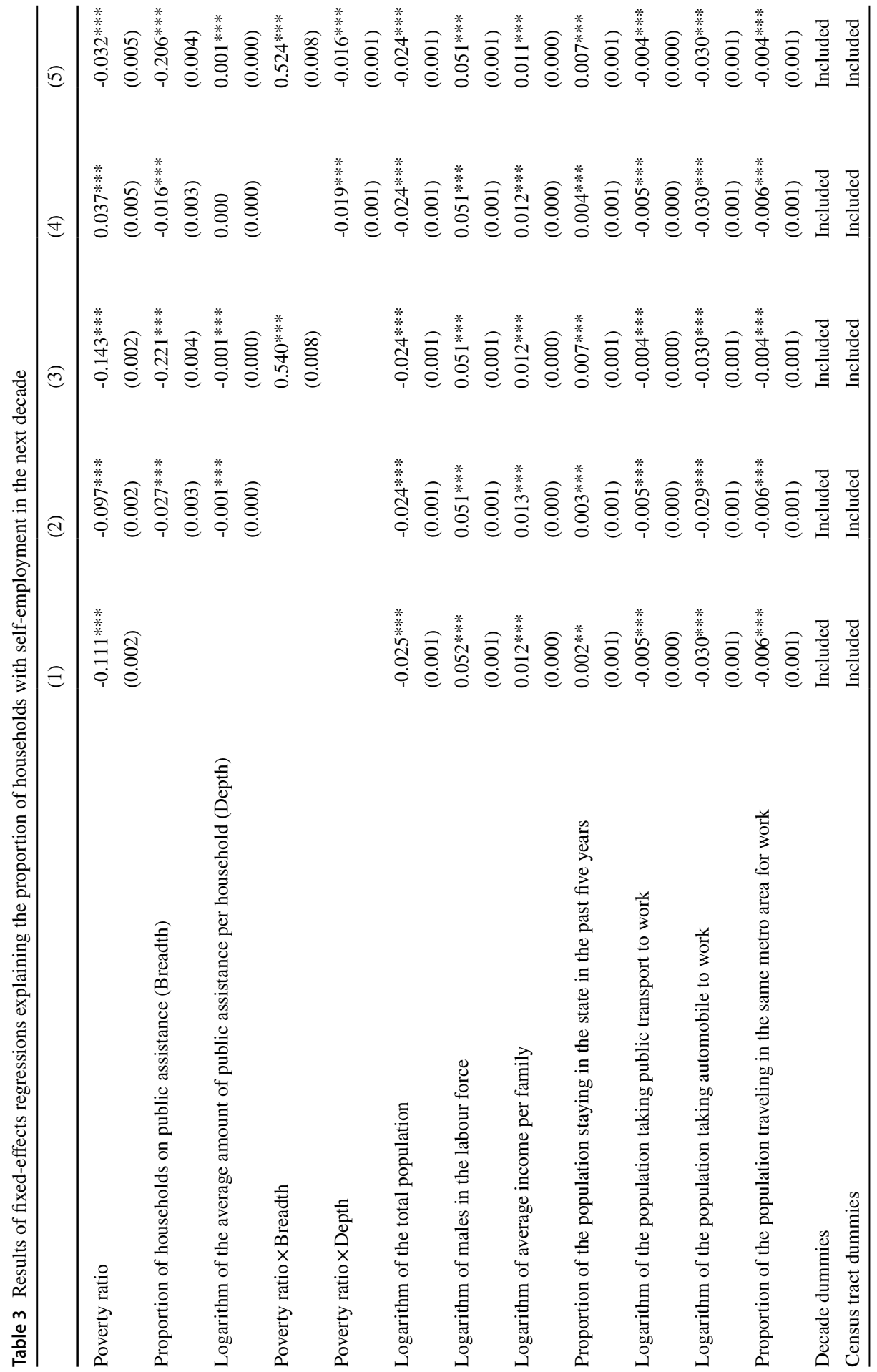




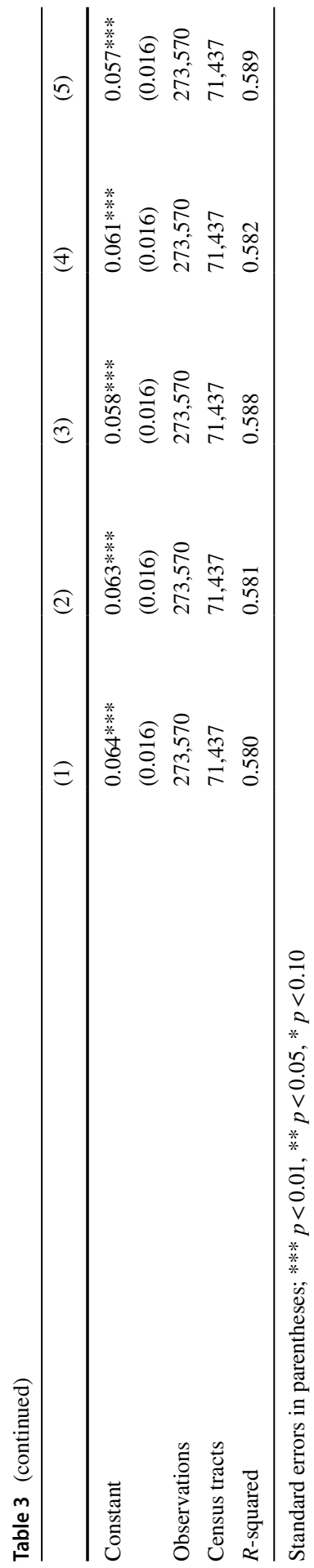



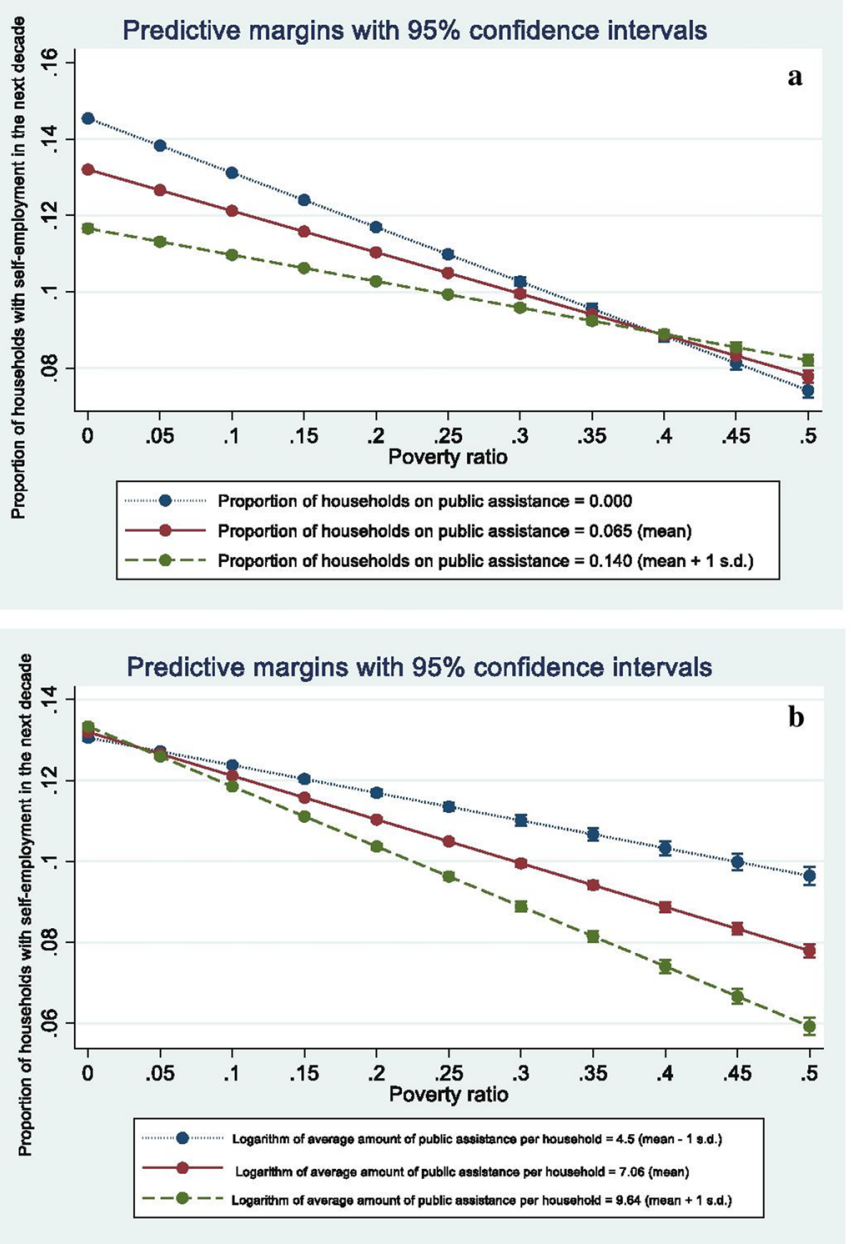

Fig. 1 a Moderation effects of the poverty rate and the proportion of households on public assistance (breadth) on the proportion of household with self-employment in the next decade. b Moderation effects of the poverty rate and the logarithm of the average amount of public assistance per household (depth) on the proportion of household with self-employment in the next decade

of public assistance is still significantly negative but the coefficient for the depth of public assistance has turned marginally positive. The sizes of the interaction effects in Column 5 are similar to those in Columns 3 and 4.

Figure 1a visualizes the interaction between the poverty ratio and the breadth of public assistance and shows that with an increasing poverty ratio the proportion of households with self-employment declines slower if the breadth of public assistance is higher. Figure $1 \mathrm{~b}$ illustrates that with an increasing poverty ratio, the proportion of households with self-employment in the next decade declines with 
higher household assistance (dashed line). However, it declines at a slower pace in census tracts receiving lower average household assistance (dotted line).

The census aims to collect representative, factual, data about the current state and development of the population, and does therefore not collect information about the motivations and aspirations of citizens. Nevertheless, since the advent of the Global Entrepreneurship Monitor (Reynolds 2002), it is common to distinguish between opportunity-driven and necessity-driven self-employment. In the GEM, motivations are directly assessed using self-reports about motivations for engaging in self-employment. Survey-based studies often use information about the prior job to distinguish the two types of self-employment. For example, Block and Sandner (2009) classify a self-employed person who left his or her previous job in paid employment on his or her own as self-employed out of opportunity, whereas a self-employed who was either dismissed by his or her employer or laid off due to a closing down of their workplace is considered to be a self-employed out of necessity. To make such a distinction, individual level data is necessary. However, our data entails information aggregated at the census-tract level.

As the proportion of necessity self-employment may be relatively high in poor census tracts (Urbano and Aparicio 2016), we analysed subsamples of poor census tracts as well as subsamples from which poor census tracts were excluded to somewhat assess with what type of self-employment the poverty ratio and its interactions with public assistance is associated. Exclusions are based on the proportion of households in the census tract receiving public assistance as well as on the poverty ratio. Table 4 present the results of these subsample analyses. Importantly, the association between the poverty ratio and household self-employment is positive in relatively poor census tracts (Columns 1-2 and 5-6) and negative in relatively rich census tracts (Columns 3-4 and 7-8). These relationships are in line with earlier studies showing that necessity entrepreneurship peaks in disadvantaged contexts, and that in wealthier areas employment in larger businesses rises. With regards to the interaction between the poverty ratio and the breadth of public assistance, we find that the effect is positive in both relatively poor census tracts (Columns 1-2 and 5-6) and relatively rich census tracts (Columns 3-4 and 7-8). The effect sizes are largest in the richest census tracts. The interaction terms between the poverty ratio and the depth of public assistance are insignificant or significantly negative (as in Table 3). Together, these results suggest that public assistance is associated with different types of self-employment across census tracts. Again, these inferences are somewhat speculative because we cannot observe the extent of opportunity or necessity-driven self-employment at the aggregate level in the dataset.

\subsection{Robustness checks}

To verify the robustness of the main findings, we conducted a series of robustness checks.

First, we used characteristics of neighbouring census tracts to control for the spatial dependence among adjacent geographical neighbourhoods (Appendix 
3 Table 5). The unit of analysis in our study is a census tract. However, the census tract exists in the milieu of social, economic, and cultural conditions of neighboring census tracts. The flow of resources, values, and beliefs in a census tract could spillover into neighbouring census tracts. For example, economic growth or decline from neighboring tracts could spillover into the focal tract to influence economic activity. Similarly, individuals may travel from the focal tract to a neighbouring tract to seek economic opportunities or vice versa. Census tracts are also nested in congressional districts, implying that political representatives from congressional districts may devise policies shared across neighboring census tracts. Overall, the spatial co-dependence among neighboring tracts is important to consider because of its potentially biasing impact on the estimated relationships.

To control for the spatial dependence among neighbouring census tracts, we identified all the neighbouring census tracts within 25 miles of the focal census tract. The combined number of neighbour census tracts totalled to about 27 million neighbouring census tracts. Though the traditional methods for spatial regression are desirable to use, in the current case we are unable to run the typical spatial regression specification due to the substantially large size of the relatedness matrix $(71,437 \times 71,437)$ and the computing power available to us. Instead, we used the census tract neighbour distance data from the National Bureau of Economic Research (NBER) ${ }^{6}$ to determine all census tracts within a 25 -mile radius from the focal tract. We included the means of the proportion of households with self-employment, the poverty ratio, the breadth and depth of public assistance, as well as the means of all regular control variables in these neighbouring census tracts as additional control variables in the regression. By controlling for the mean of the characteristics of neighbouring census tracts, we deal with the possible influence of economic, social, and local spillovers across neighbouring census tracts. Sample sizes for these regressions are somewhat smaller as compared to the main analysis, because of some missing information about characteristics of neighbouring census tracts.

Although our inferences from the results of these analyses, as reported in Appendix 3 Table 5, are fairly similar to our inferences from the main analyses. Most importantly, we find again support for $\mathrm{H} 1$ and $\mathrm{H} 2$, but not for $\mathrm{H} 3$. However, we note that the coefficient for the interaction between the poverty ratio and depth of public assistance has halved (H3). Being significantly negative in both Table 3 and Appendix 3 Table 5, the size of the coefficient shrunk from -0.016 to -0.007 . Hence, based on this robustness check, we conclude that the surprisingly negative coefficient for the interaction between the poverty ratio and the depth of public assistance we found in Table 3 seems to quite an extent driven by the geographical proximity among census tracts in the analysis sample. In other words, after including the neighboring census tract confounds in the model, the effect size of the interaction between the poverty ratio and the depth of public assistance is negligible. Therefore, these results suggest that spillovers from the

\footnotetext{
${ }^{6}$ Source: https://data.nber.org/data/census-tract-distance-database.html [Retrieved: April 1, 2020].
} 


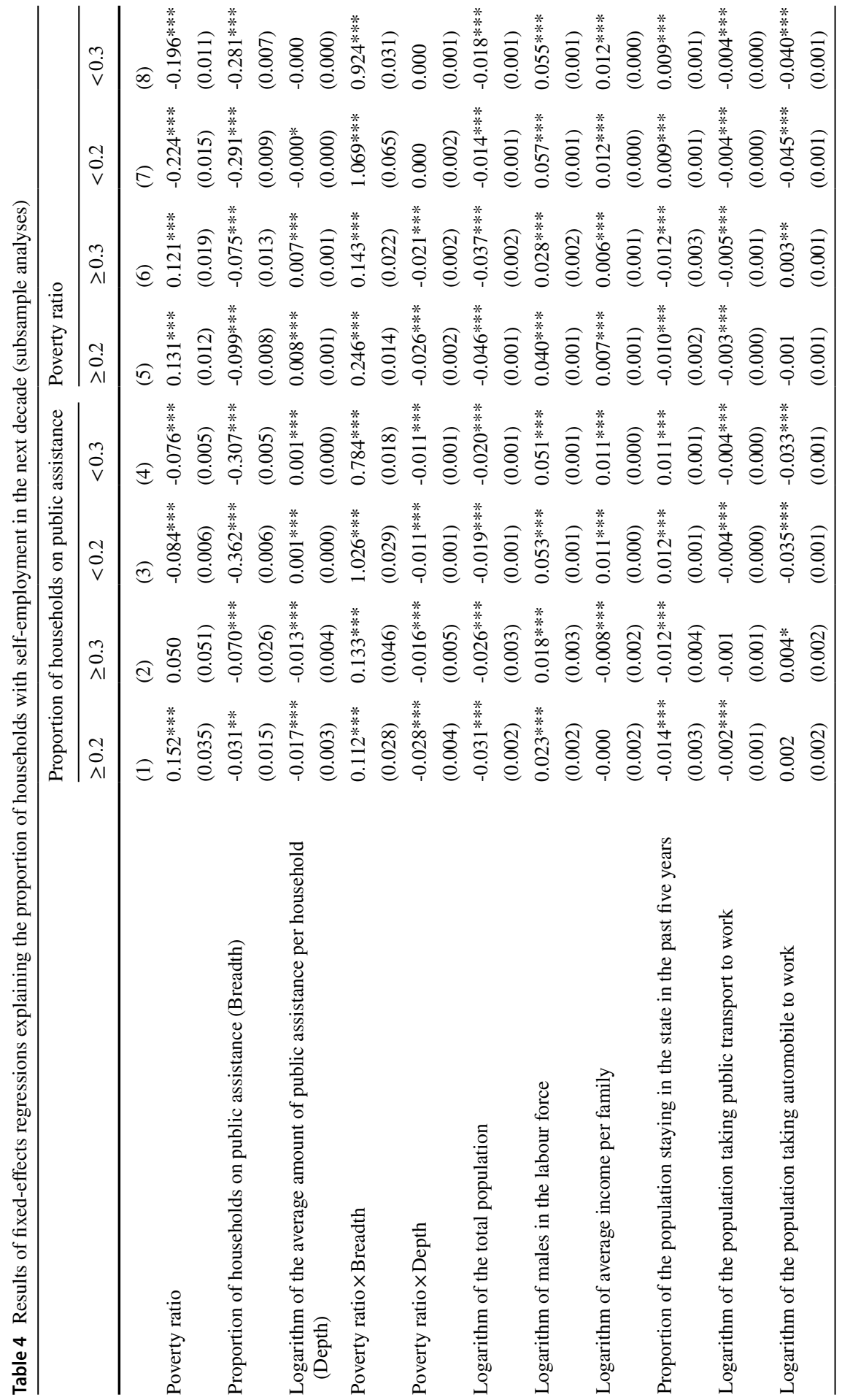




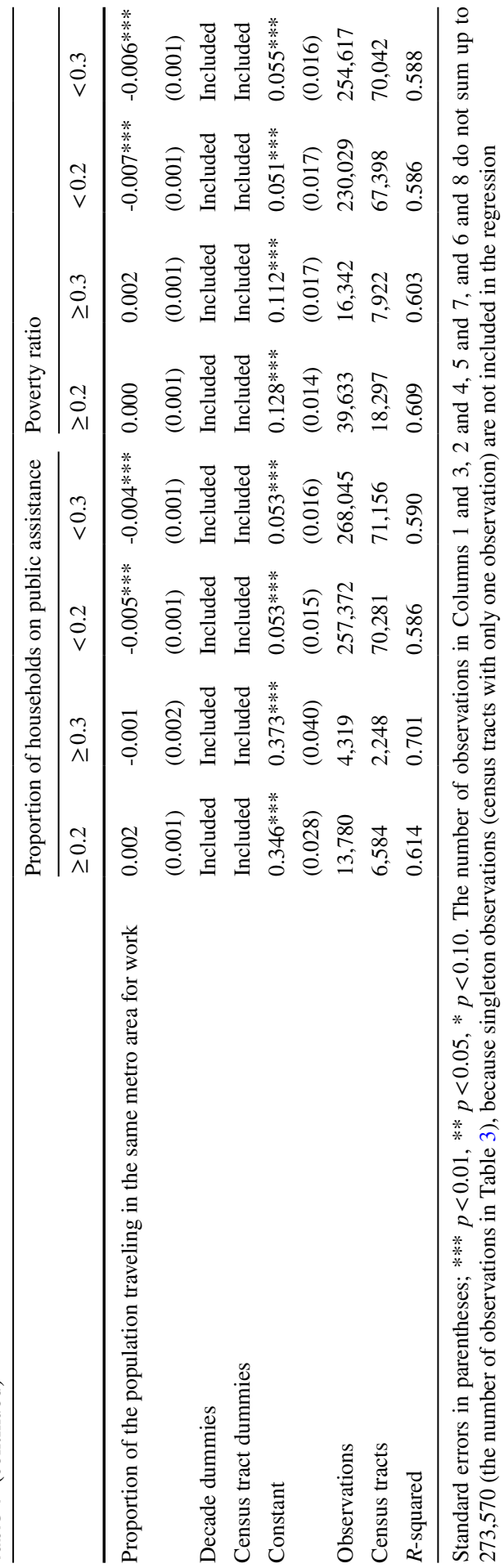


neighbouring census tracts contribute to the interaction effect as estimated in Table 3.

Second, we analysed a specification in which we used two-way standard error clustering to deal with shared covariances among census tracts in the same state. Year shocks census tracts experience may co-vary within a state. As such, the observations of census tracts at the state-decade level may have shared covariances. In line with Cameron and Miller (2015) and Bertrand et al. (2004), we, therefore, cluster census tract observations at the state-decade level. The estimates for the coefficients remain the same in these models, but with this robustness check, we reevaluate the uncertainty surrounding the estimates. Appendix 3 Table 6 shows that the results of these regressions are consistent with the main inferences. Therefore, we conclude that covariances between census tracts within a state are not driving our main results.

Third, we used a placebo test in which we shuffled breadth and depth of public assistance within state-decade combinations to analyse to what extent variation across states and decades in terms of available types of public assistance and their take-up is driving the results. Our dataset contains information about the total amount of public assistance received but does not include information about the different types of programs this assistance comes from. However, state-level variations in public assistance policies and internal dynamics within a census tract may impact the availability and uptake of public assistance. When comparing census tracts in terms of the total amount of public assistance received, it may, therefore, be possible that we draw incorrect inferences about the effect of public assistance. To lower these concerns, we conducted a placebo test by shuffling breadth and depth across census tracts within each state-decade combination. If this randomization does not change the estimated effects, then these effects cannot be attributed uniquely to public assistance within a census tract but they should be attributed to factors related to variation across states and decades. Reassuringly, Appendix 3 Table 7 (Model 5) shows that the coefficient for the (placebo) breadth of public assistance is significant but marginally small. The coefficient for the interaction term between the poverty ratio and (placebo) breadth of public assistance is also significant and small. Moreover, its sign is the opposite as compared to Model 10 in Table 3. Both the coefficient for the depth of public assistance and its interaction with the poverty ratio are insignificant. Therefore, we conclude that the estimated effects in our main analysis are largely attributable to unique effects within a census tract.

Based on these robustness checks, we conclude that the surprisingly negative coefficient we found in Table 3 for the interaction between the poverty ratio and depth of public assistance seems to quite an extent driven by the geographical proximity among census tracts in the analysis sample. However, covariances between census tracts within a state are not driving our main results and the estimated relationships in our main analysis are largely attributable to unique associations within a census tract. 


\section{Discussion and conclusion}

Poverty is an ineradicable problem affecting many, not only in developing countries but also in developed countries like the US (Proctor et al. 2016). The primary goal of our paper was to provide evidence on the long-term association between antipoverty policies, aggregated as public assistance, and a key outcome of socioeconomic importance, self-employment. By appreciating the liability of poorness (Morris et al. 2020a) and by building from the study by Neumark et al. (2019) about broader outcomes of employment and earnings, we focused on the prevalence of self-employment as it is central to long-term self-sufficiency and economic vitality. By extending prior works on the role of self-employment as a mode of lowering poverty and by analysing decennial data over four decades, we find that the poverty ratio in a census tract is negatively associated with the prevalence of selfemployment one decade later. The breadth rather than the depth of public assistance mitigates the negative association. We infer that though public assistance may not lead to increased levels of self-employment, it lowers the decline in the level of self-employment.

Our findings are informative for several streams of literature. First, we provide a longer temporal arc to improve our understanding of the aggregate implications of poverty alleviating policies on self-employment and thus extend the literature on poverty and entrepreneurship that has focused on the resource provision and empowering role of institutions and the government in promoting self-employment. The local self-employment levels are salient as self-employment is driven by both individual and institutional factors. Though social and institutional changes are unpredictable and uncertain (Thornton et al. 2015), communities leveraging local input and knowledge could help better transform the local economic conditions. The need for public assistance may, therefore, be more necessary in marginalized populations and our findings indicate that greater breadth of public assistance in marginalized areas may be central to improving entrepreneurial activity. Though there are increased calls for changing the institutional context (e.g., regulation), breadth of public assistance aims to provide grassroots level impetus to improve local economic and social logics for exploiting entrepreneurial opportunities (Hoogendoorn 2016).

Second, related to the broader entrepreneurship research, Shane (2009) cautions against government programs aimed at increasing self-employment in economically disadvantaged areas. Though our study is not directly about government-sponsored programs aimed at promoting self-employment in economically disadvantaged areas, our study extends this prior 'outcome' oriented research and finds that breadth, but not the depth of public assistance, alleviates the negative association between poverty and self-employment. Despite our expectation that the depth of public assistance would also have such a relationship with the poverty ratio, our robustness analysis revealed that this relationship should be partially explained by the geographical distribution of economic activity. Koellinger and Minniti (2009) found country-level evidence that higher unemployment benefits, a 
form of public assistance, could crowd out the nascent entrepreneurial activity by increasing the opportunity costs of starting a business. Such a mechanism may lie behind the surprisingly negative (but small) association we find between the poverty ratio and the depth of public assistance on the one hand and self-employment on the other hand. Hence, although we caution that our findings do not point to improvements in economic health as a result of higher levels of self-employment, our findings suggest that the aggregate economic empowerment of census tracts (breadth) is more effective than given larger shares of money to smaller groups of people (depth). As such, our findings are informative about how to spend money on welfare benefits.

Third, our findings contribute to the literature on the economic geography of entrepreneurship (Karlsson and Dahlberg 2003; Sorenson 2017; Yeung 2009). The spatial dimension is a basic constituting factor of entrepreneurship. Favourable geographic conditions including the presence of local investors, incubators, accessibility, and diversity of the environment, and knowledge stocks are some of the key elements driving entrepreneurship. However, in this literature, there is a limited understanding of self-employment in more disadvantaged regions. The current findings indicate that a long-term approach may be desirable to explain the evolution of household participation in self-employment. As such, our study warrants further analysis of the geographical conditions behind the low selfemployment rate in poor neighbourhoods. Morris et al. (2020b) also emphasize this dimension in their SPODER framework that they developed to foster entrepreneurial development among the poor. The SPODER framework refers to supportive infrastructure $(\mathrm{S})$, preparation of the entrepreneur $(\mathrm{P})$; expanded opportunity horizons (O); finding sources of differentiation (D); (E) a well-designed economic model $(\mathrm{E})$; and leveraging community resources $(\mathrm{R})$. The provision of public assistance may indeed be related to improved supportive infrastructure and a greater opportunity to leverage community resources. Akin to rising tide raising all the ships, public assistance may improve the overall climate and income levels to not only lower intense pressures and lack of resources, but it may also improve the overall local climate towards self-employment and economic self-sufficiency.

Some practical implications of these findings are as follows. Due to the generally limited budgets for public assistance programs, the challenge is often whether to spread smaller amounts to a large number of individuals or increasing the depth by providing more funds to those in most need. Though the depth vs. breadth of public assistance tradeoff goes beyond the simple economic calculus, our findings show that when increasing self-employment prevalence is the overarching goal, breadth of public assistance may be necessary for the long-term planning of public assistance programs. Subsample analyses show that this strategy could be viable both in poor and rich neighbourhoods, although the provision of public assistance seems particularly associated with fostering opportunity self-employment in richer areas. Selfemployment is related to country-level economic growth (Blanchflower 2000) and regional growth (Tsvetkova et al. 2019), and a large body of work shows 
that self-employment may be driven by push-based factors to avoid joblessness (Falco and Haywood 2016; Liang and Goetz 2016). However, in a country-level study, Thurik et al. (2008) find that even push-based self-employment (i.e., undertaken out of necessity) may lower unemployment in the longer term. Relatedly, in the context of developing countries, self-employment in the informal sector, generally sustenance-based entrepreneurship, is associated with lower poverty levels (Fields 2019). Thus, even low value-creating self-employment could potentially improve unemployment rates and enhance the overall economic and social climate in such neighbourhoods.

Our study is not without limitations and these limitations could be addressed in future research. First, the measurement of self-employment in our study requires further discussion. Although the census data are reliable with regards to formal activities, the coarseness in reporting formal activities and aggregation at the household level may induce systematic measurement errors. For example, we are unable to distinguish formal from informal self-employment and to parse out the number of individuals engaged in self-employment in a household and the number of hours worked in self-employment by participating members. All these factors may to some extent be associated with the poverty ratio in a census tract. Relatedly, despite our subsample analyses, with our data, we are not able to explicitly distinguish between opportunity-based (driven by a profitable opportunity) and necessity-based (driven by lack of other employment alternatives) entrepreneurship. Although our data are not suitable for this, future studies could try to further parse out these nuances. More generally, we note that we focused on self-employment rather than entrepreneurship in our study. Selfemployment is related to but distinct from entrepreneurship. While entrepreneurs are generally focused on establishing high-growth firms, the self-employed are either part of non-employer establishments (e.g., freelancers or contractors) or small business owners less focused on growth. In our context, self-employment is a viable outcome variable as we do not expect high-growth entrepreneurship to be prevalent in economically disadvantaged areas, though it would be a socially and economically desirable outcome. Small businesses also employ a significant portion of the workforce and are important members of the entrepreneurial ecosystem. However, their average impact on economic development is not as large as that of entrepreneurs.

Another limitation refers to the reporting of aggregate welfare payment receipts in the census. As such, we are unable to parse out the relationship between individual welfare payments and self-employment. As argued before, the landscape of public assistance programs in the US is highly fragmented with a multitude of policies operational at state and federal levels. This makes it difficult to reconcile the idiosyncrasies of state-federal policy combinations. To assess the ecological validity of our inferences, we conducted a placebo test that helps overcome some of the limitations by ensuring that the aggregate reported public assistance payments are indeed applicable to the census tract during a decade. Despite this limitation, we believe the census provides the most appropriate data for our analysis because residents are 
obliged to fill in the census form due to the federal law requiring a response. Also, to our knowledge, it is the best available data on aggregate welfare breadth and depth at the smallest possible geographical unit, the census tract. The Survey of Income and Program Participation (SIPP), the American Community Survey (ACS), and the Current Population Survey (CPS) provide data on whether one receives a particular type of welfare, but do not cover the full-time frame (most data starts in the mid1980s) or do not provide sufficiently fine-grained location data, or a combination of these two limitations.

In conclusion, in this study, we took a long-term perspective to assess the relationship between the breadth and depth of public assistance and household selfemployment in US neighbourhoods. Though studies on income inequality highlight the impetus of poverty in increasing participation in self-employment, our results show that the poverty ratio lowers the prevalence of self-employment. In managing trade-offs between breadth and depth of public assistance, breadth seems to better mitigate the negative relationship between the poverty ratio and self-employment. Our findings provide policymakers a long-term perspective about the allocation of public assistance and offer a new perspective to the literature on self-employment and poverty.

\section{Appendix 1}

\section{Brief historical overview of safety net programs in the US}

Over the past 50 years, a variety of safety net programs have been added or expanded to alleviate poverty and to meet the basic needs of poor families. Most programs are means-test based (qualification based on income and asset level) and carry a work requirement for able-bodied individuals. Though the provision of a full list of safety programs at the federal and state level is beyond the scope of this work, some of the major additions over the years have been the Supplemental Security Income (SSI; 1972), the Women, Infants, and Children (WIC; 1972), the Earned Income Tax Credit (EITC; 1975), the child support program (1975), the Low Income Home Energy Assistance Program (LIHEAP; 1981), Children's Health Insurance Program (CHIP; 1997), Medicare Part D (Low Income Subsidy; 2003), and most recently the Affordable Care Act (ACA; 2010).

The SSI provides cash assistance to seniors and disabled, the Temporary Assistance for Needy Families (TANF) provides grants to states for cash assistance to poor families with children, and EITC provides tax credits to low-income workers. The Supplemental Nutrition Assistance Program (SNAP) provides food subsidies to low-income households through debit cards (EBT payment system), and the Child Nutrition Program provides free or subsidized breakfasts and lunches to children. As such, the qualification, mode of payment, and the beneficiaries vary by program. We refer to Moffitt (2015) for a more elaborate overview of the federal 
benefits programs and the current expanse of these programs. The federal budget for these programs was $\$ 2.5$ trillion in 2018. In this year, about $55 \%$ of the households received some form of cash or in-kind assistance from at least one federal program, and 58 percent of the children were growing up in a family receiving some form of public assistance. $^{7}$

\section{Appendix 2}

Figure 2

\section{Census Small-Area Geography}

\section{Understanding the Relationships Among U.S. Census Bureau Geographic Entities}

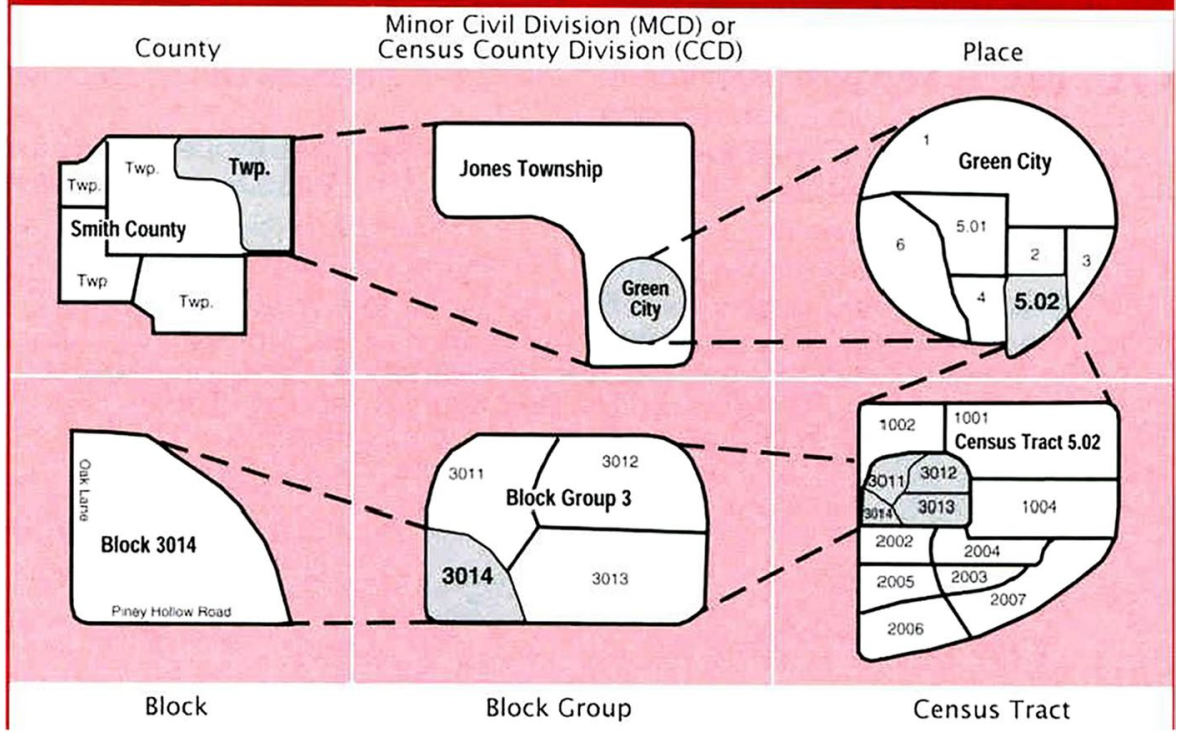

Fig. 2 An example of a census tract. Source:https://pitt.libguides.com/uscensus/understandinggeograp hy

\footnotetext{
${ }^{7}$ Source: https://www.policyed.org/policy-insights/social-safety-nets.
} 


\section{Appendix 3}

Tables 5, 6, 7

Table 5 Results of fixed-effects regressions explaining the proportion of households with self-employment in the next decade (additional control variables for characteristics of neighbouring census tracts)

\begin{tabular}{|c|c|c|c|}
\hline & (1) & (2) & (3) \\
\hline Poverty ratio & $\begin{array}{l}-0.124 * * * \\
(0.002)\end{array}$ & $\begin{array}{l}-0.096^{* * *} \\
(0.002)\end{array}$ & $\begin{array}{l}-0.095^{* * *} \\
(0.006)\end{array}$ \\
\hline $\begin{array}{l}\text { Proportion of households on public assistance } \\
\text { (Breadth) }\end{array}$ & & $(0.003)$ & $(0.005)$ \\
\hline $\begin{array}{l}\text { Logarithm of the average amount of public assistance } \\
\text { per household (Depth) }\end{array}$ & & $\begin{array}{l}-0.002 * * * \\
(0.000)\end{array}$ & $\begin{array}{l}-0.001 * * * \\
(0.000)\end{array}$ \\
\hline Poverty ratio $\times$ Breadth & & & $\begin{array}{l}0.550^{* * *} \\
(0.009)\end{array}$ \\
\hline Poverty ratio $\times$ Depth & & & $\begin{array}{l}-0.007 * * * \\
(0.001)\end{array}$ \\
\hline Logarithm of the total population & $\begin{array}{l}-0.024 * * * \\
(0.001)\end{array}$ & $\begin{array}{l}-0.022 * * * \\
(0.001)\end{array}$ & $\begin{array}{l}-0.024 * * * \\
(0.001)\end{array}$ \\
\hline Logarithm of males in the labour force & $\begin{array}{l}0.049 * * * \\
(0.001)\end{array}$ & $\begin{array}{l}0.048 * * * \\
(0.001)\end{array}$ & $\begin{array}{l}0.048^{* * * *} \\
(0.001)\end{array}$ \\
\hline Logarithm of average income per family & $\begin{array}{l}0.018 * * * \\
(0.000)\end{array}$ & $\begin{array}{l}0.018 * * * \\
(0.000)\end{array}$ & $\begin{array}{l}0.017 * * * \\
(0.000)\end{array}$ \\
\hline $\begin{array}{l}\text { Proportion of the population staying in the state in the } \\
\text { past five years }\end{array}$ & $\begin{array}{l}0.001 \\
(0.001)\end{array}$ & $\begin{array}{l}0.004 * * * \\
(0.001)\end{array}$ & $\begin{array}{l}0.006 * * * \\
(0.001)\end{array}$ \\
\hline $\begin{array}{l}\text { Logarithm of the population taking public transport } \\
\text { to work }\end{array}$ & $\begin{array}{l}-0.004 * * * \\
(0.000)\end{array}$ & $\begin{array}{l}-0.004 * * * \\
(0.000)\end{array}$ & $\begin{array}{l}-0.004 * * * \\
(0.000)\end{array}$ \\
\hline $\begin{array}{l}\text { Logarithm of the population taking automobile to } \\
\text { work }\end{array}$ & $\begin{array}{l}-0.033 * * * \\
(0.001)\end{array}$ & $\begin{array}{l}-0.033 * * * \\
(0.001)\end{array}$ & $\begin{array}{l}-0.032 * * * \\
(0.001)\end{array}$ \\
\hline $\begin{array}{l}\text { Proportion of the population traveling in the same } \\
\text { metro area for work }\end{array}$ & $\begin{array}{l}-0.003 * * * \\
(0.001)\end{array}$ & $\begin{array}{l}-0.003 * * * \\
(0.001)\end{array}$ & $\begin{array}{l}-0.002 * * * \\
(0.001)\end{array}$ \\
\hline $\begin{array}{l}\text { Mean proportion of households with self-employment } \\
\text { in neighbouring census tracts }\end{array}$ & $\begin{array}{l}-0.045^{* * * *} \\
(0.008)\end{array}$ & $\begin{array}{l}-0.046^{* * * *} \\
(0.008)\end{array}$ & $\begin{array}{l}-0.044 * * * \\
(0.008)\end{array}$ \\
\hline Mean poverty ratio in neighbouring census tracts & $\begin{array}{l}0.041 * * * \\
(0.012)\end{array}$ & $\begin{array}{l}0.050^{* * * *} \\
(0.012)\end{array}$ & $\begin{array}{l}0.050^{* * *} \\
(0.012)\end{array}$ \\
\hline $\begin{array}{l}\text { Mean proportion of households on public assistance } \\
\text { (Breadth) in neighbouring census tracts }\end{array}$ & $\begin{array}{l}-0.011 \\
(0.021)\end{array}$ & $\begin{array}{l}-0.028 \\
(0.021)\end{array}$ & $\begin{array}{l}-0.034 \\
(0.021)\end{array}$ \\
\hline $\begin{array}{l}\text { Mean logarithm of the average amount of public } \\
\text { assistance per household (Depth) in neighbouring } \\
\text { census tracts }\end{array}$ & $\begin{array}{l}0.001 \\
(0.001)\end{array}$ & $\begin{array}{l}0.000 \\
(0.001)\end{array}$ & $\begin{array}{l}0.000 \\
(0.001)\end{array}$ \\
\hline $\begin{array}{l}\text { Mean logarithm of the total population in neighbour- } \\
\text { ing census tracts }\end{array}$ & $\begin{array}{l}-0.010 * * * \\
(0.003)\end{array}$ & $\begin{array}{l}-0.009 * * * \\
(0.003)\end{array}$ & $\begin{array}{l}-0.008 * * * \\
(0.003)\end{array}$ \\
\hline $\begin{array}{l}\text { Mean logarithm of males in the labour force in neigh- } \\
\text { bouring census tracts }\end{array}$ & $\begin{array}{l}0.006^{*} \\
(0.003)\end{array}$ & $\begin{array}{l}0.005 \\
(0.003)\end{array}$ & $\begin{array}{l}0.005 \\
(0.003)\end{array}$ \\
\hline
\end{tabular}


Table 5 (continued)

\begin{tabular}{|c|c|c|c|}
\hline & (1) & (2) & (3) \\
\hline \multirow{2}{*}{$\begin{array}{l}\text { Mean logarithm of average income per family in } \\
\text { neighbouring census tracts }\end{array}$} & $0.003 * *$ & $0.003 * *$ & $0.002 *$ \\
\hline & $(0.001)$ & $(0.001)$ & $(0.001)$ \\
\hline \multirow{2}{*}{$\begin{array}{l}\text { Mean proportion of the population staying in the state } \\
\text { in the past five years in neighbouring census tracts }\end{array}$} & $-0.014 * *$ & $-0.012 *$ & $-0.012 *$ \\
\hline & $(0.006)$ & $(0.006)$ & $(0.006)$ \\
\hline \multirow{2}{*}{$\begin{array}{l}\text { Mean logarithm of the population taking public trans- } \\
\text { port to work in neighbouring census tracts }\end{array}$} & 0.000 & 0.000 & 0.000 \\
\hline & $(0.000)$ & $(0.000)$ & $(0.000)$ \\
\hline \multirow{2}{*}{$\begin{array}{l}\text { Mean logarithm of the population taking automobile } \\
\text { to work in neighbouring census tracts }\end{array}$} & $-0.015^{* * *}$ & $-0.015 * * *$ & $-0.016^{* * *}$ \\
\hline & $(0.002)$ & $(0.002)$ & $(0.002)$ \\
\hline \multirow{2}{*}{$\begin{array}{l}\text { Mean proportion of the population traveling in the } \\
\text { same metro area for work in neighbouring census } \\
\text { tracts }\end{array}$} & $-0.003 * * *$ & $-0.003 * * *$ & $-0.004 * * *$ \\
\hline & $(0.000)$ & $(0.000)$ & $(0.000)$ \\
\hline Decade dummies & Included & Included & Included \\
\hline Census tract dummies & Included & Included & Included \\
\hline \multirow[t]{2}{*}{ Constant } & $0.073 * * *$ & $0.073 * * *$ & $0.072 * * *$ \\
\hline & $(0.027)$ & $(0.027)$ & $(0.027)$ \\
\hline Observations & 187,436 & 187,436 & 187,436 \\
\hline Census tracts & 50,195 & 50,195 & 50,195 \\
\hline$R$-squared & 0.578 & 0.58 & 0.588 \\
\hline
\end{tabular}

Standard errors in parentheses; $* * * p<0.01, * * p<0.05, * p<0.10$ 
Table 6 Results of fixed-effects regressions explaining the proportion of households with self-employment in the next decade (standard errors clustered by state $\times$ decade)

\begin{tabular}{|c|c|c|c|}
\hline & (1) & (2) & (3) \\
\hline Poverty ratio & $\begin{array}{l}-0.111 * * * \\
(0.006)\end{array}$ & $\begin{array}{l}-0.097 * * * \\
(0.007)\end{array}$ & $\begin{array}{l}-0.032 \\
(0.025)\end{array}$ \\
\hline Proportion of households on public assistance (Breadth) & & $\begin{array}{l}-0.027 * * \\
(0.012)\end{array}$ & $\begin{array}{l}-0.206^{* * * *} \\
(0.015)\end{array}$ \\
\hline $\begin{array}{l}\text { Logarithm of the average amount of public assistance per household } \\
\text { (Depth) }\end{array}$ & & $\begin{array}{l}-0.001 * * * \\
(0.000)\end{array}$ & $\begin{array}{l}0.001 \\
(0.000)\end{array}$ \\
\hline Poverty ratio $\times$ Breadth & & & $\begin{array}{l}0.524 * * * \\
(0.040)\end{array}$ \\
\hline Poverty ratio $\times$ Depth & & & $\begin{array}{l}-0.016^{* * * *} \\
(0.003)\end{array}$ \\
\hline Logarithm of the total population & $\begin{array}{l}-0.025^{* * *} \\
(0.002)\end{array}$ & $\begin{array}{l}-0.024 * * * \\
(0.003)\end{array}$ & $\begin{array}{l}-0.024 * * * \\
(0.002)\end{array}$ \\
\hline Logarithm of males in the labour force & $\begin{array}{l}0.052 * * * \\
(0.002)\end{array}$ & $\begin{array}{l}0.051 * * * \\
(0.002)\end{array}$ & $\begin{array}{l}0.051 * * * \\
(0.002)\end{array}$ \\
\hline Logarithm of average income per family & $\begin{array}{l}0.012 * * * \\
(0.001)\end{array}$ & $\begin{array}{l}0.013 * * * \\
(0.001)\end{array}$ & $\begin{array}{l}0.011 * * * \\
(0.001)\end{array}$ \\
\hline Proportion of the population staying in the state in the past five years & $\begin{array}{l}0.002 \\
(0.002)\end{array}$ & $\begin{array}{l}0.003^{*} \\
(0.002)\end{array}$ & $\begin{array}{l}0.007 * * * \\
(0.002)\end{array}$ \\
\hline Logarithm of the population taking public transport to work & $\begin{array}{l}-0.005^{* * *} \\
(0.000)\end{array}$ & $\begin{array}{l}-0.005^{* * *} * \\
(0.000)\end{array}$ & $\begin{array}{l}-0.004 * * * \\
(0.000)\end{array}$ \\
\hline Logarithm of the population taking automobile to work & $\begin{array}{l}-0.030^{* * *} \\
(0.002)\end{array}$ & $\begin{array}{l}-0.029 * * * \\
(0.002)\end{array}$ & $\begin{array}{l}-0.030 * * * \\
(0.002)\end{array}$ \\
\hline $\begin{array}{l}\text { Proportion of the population traveling in the same metro area for } \\
\text { work }\end{array}$ & $\begin{array}{l}-0.006^{* * *} \\
(0.017)\end{array}$ & $\begin{array}{l}-0.006^{* * *} \\
(0.019)\end{array}$ & $\begin{array}{l}-0.004 * * * \\
(0.019)\end{array}$ \\
\hline Decade dummies & Included & Included & Included \\
\hline Census tract dummies & Included & Included & Included \\
\hline Constant & $\begin{array}{l}0.064 * * \\
(0.025)\end{array}$ & $\begin{array}{l}0.063 * * \\
(0.025)\end{array}$ & $\begin{array}{l}0.057 * * \\
(0.025)\end{array}$ \\
\hline Observations & 273,570 & 273,570 & 273,570 \\
\hline Census tracts & 71,437 & 71,437 & 71,437 \\
\hline$R$-squared & 0.580 & 0.581 & 0.589 \\
\hline
\end{tabular}

Standard errors in parentheses; $* * * p<0.01, * * p<0.05, * p<0.10$ 
Table 7 Results of fixed-effects regressions explaining the proportion of households with self-employment in the next decade (placebo test)

\begin{tabular}{|c|c|c|c|c|c|}
\hline & (1) & (2) & (3) & (4) & (5) \\
\hline Poverty ratio & $\begin{array}{l}-0.111 * * * \\
(0.002)\end{array}$ & $\begin{array}{l}-0.111 * * * \\
(0.002)\end{array}$ & $\begin{array}{l}-0.108 * * * \\
(0.002)\end{array}$ & $\begin{array}{l}-0.112^{* * *} \\
(0.003)\end{array}$ & $\begin{array}{l}-0.112 * * * \\
(0.003)\end{array}$ \\
\hline $\begin{array}{l}\text { "Placebo" proportion of households } \\
\text { on public assistance (breadth) }\end{array}$ & & $\begin{array}{l}0.000 \\
(0.001)\end{array}$ & $\begin{array}{l}0.005^{* *} \\
(0.002)\end{array}$ & $\begin{array}{l}0.000 \\
(0.001)\end{array}$ & $\begin{array}{l}0.005^{* *} \\
(0.002)\end{array}$ \\
\hline $\begin{array}{l}\text { "Placebo" logarithm of the average } \\
\text { amount of public assistance per } \\
\text { household (depth) }\end{array}$ & & $\begin{array}{l}-0.000 \\
(0.000)\end{array}$ & $\begin{array}{l}-0.000 \\
(0.000)\end{array}$ & $\begin{array}{l}-0.000 \\
(0.000)\end{array}$ & $\begin{array}{l}-0.000 \\
(0.000)\end{array}$ \\
\hline $\begin{array}{l}\text { Poverty ratio } \times \text { "Placebo" proportion } \\
\text { of households on public assistance } \\
\text { (Breadth) }\end{array}$ & & & $\begin{array}{l}-0.039 * * * \\
(0.012)\end{array}$ & & $\begin{array}{l}-0.043 * * * \\
(0.012)\end{array}$ \\
\hline $\begin{array}{l}\text { Poverty ratio } \times \text { "Placebo" logarithm } \\
\text { of the average amount of public } \\
\text { assistance per household (Depth) }\end{array}$ & & & & $\begin{array}{l}0.000 \\
(0.000)\end{array}$ & $\begin{array}{l}0.001 \\
(0.000)\end{array}$ \\
\hline Logarithm of the total population & $\begin{array}{l}-0.025^{* * *} \\
(0.001)\end{array}$ & $\begin{array}{l}-0.025 * * * \\
(0.001)\end{array}$ & $\begin{array}{l}-0.025 * * * \\
(0.001)\end{array}$ & $\begin{array}{l}-0.025 * * * \\
(0.001)\end{array}$ & $\begin{array}{l}-0.025 * * * \\
(0.001)\end{array}$ \\
\hline $\begin{array}{l}\text { Logarithm of males in the labour } \\
\text { force }\end{array}$ & $0.052 * * *$ & $0.052 * * *$ & $0.052 * * *$ & $0.052 * * *$ & $0.052 * * *$ \\
\hline $\begin{array}{l}\text { Logarithm of average income per } \\
\text { family }\end{array}$ & $0.012^{* * * *}$ & $0.012 * * *$ & $0.012 * * *$ & $0.012 * * *$ & $0.012 * * *$ \\
\hline $\begin{array}{l}\text { Proportion of the population staying } \\
\text { in the state in the past five years }\end{array}$ & $\begin{array}{l}0.002 * * \\
(0.001)\end{array}$ & $\begin{array}{l}0.002 * * \\
(0.001)\end{array}$ & $\begin{array}{l}0.002 * * \\
(0.001)\end{array}$ & $\begin{array}{l}0.002 * * \\
(0.001)\end{array}$ & $\begin{array}{l}0.002 * * \\
(0.001)\end{array}$ \\
\hline $\begin{array}{l}\text { Logarithm of the population taking } \\
\text { public transport to work }\end{array}$ & $\begin{array}{l}-0.005^{* * *} \\
(0.000)\end{array}$ & $\begin{array}{l}-0.005 * * * \\
(0.000)\end{array}$ & $\begin{array}{l}-0.005 * * * \\
(0.000)\end{array}$ & $\begin{array}{l}-0.005 * * * \\
(0.000)\end{array}$ & $\begin{array}{l}-0.005 * * * \\
(0.000)\end{array}$ \\
\hline $\begin{array}{l}\text { Logarithm of the population taking } \\
\text { automobile to work }\end{array}$ & $\begin{array}{l}-0.030^{* * *} \\
(0.001)\end{array}$ & $-0.030 * * *$ & $-0.030 * * *$ & $-0.030 * * *$ & $\begin{array}{l}-0.030 * * * \\
(0.001)\end{array}$ \\
\hline $\begin{array}{l}\text { Proportion of the population trave- } \\
\text { ling in the same metro area for } \\
\text { work }\end{array}$ & $\begin{array}{l}-0.006^{* * *} \\
(0.001)\end{array}$ & $\begin{array}{l}-0.006 * * * \\
(0.001)\end{array}$ & $\begin{array}{l}-0.006 * * * \\
(0.001)\end{array}$ & $\begin{array}{l}-0.006 * * * \\
(0.001)\end{array}$ & $\begin{array}{l}-0.006^{* * * *} \\
(0.001)\end{array}$ \\
\hline Decade dummies & Included & Included & Included & Included & Included \\
\hline Census tract dummies & Included & Included & Included & Included & Included \\
\hline Constant & $\begin{array}{l}0.064 * * * \\
(0.016)\end{array}$ & $\begin{array}{l}0.064 * * * \\
(0.016)\end{array}$ & $\begin{array}{l}0.064 * * * \\
(0.016)\end{array}$ & $\begin{array}{l}0.064 * * * \\
(0.016)\end{array}$ & $\begin{array}{l}0.064 * * * \\
(0.016)\end{array}$ \\
\hline Observations & 273,570 & 273,570 & 273,570 & 273,570 & 273,570 \\
\hline Census tracts & 71,437 & 71,437 & 71,437 & 71,437 & 71,437 \\
\hline$R$-squared & 0.580 & 0.580 & 0.580 & 0.580 & 0.580 \\
\hline
\end{tabular}

Standard errors in parentheses; $* * * p<0.01, * * p<0.05, * p<0.10$ 


\section{Declarations}

Informed consent Not applicable.

Disclosure of potential conflicts of interest The authors have no conflicts of interest to declare that are relevant to the content of this article.

Open Access This article is licensed under a Creative Commons Attribution 4.0 International License, which permits use, sharing, adaptation, distribution and reproduction in any medium or format, as long as you give appropriate credit to the original author(s) and the source, provide a link to the Creative Commons licence, and indicate if changes were made. The images or other third party material in this article are included in the article's Creative Commons licence, unless indicated otherwise in a credit line to the material. If material is not included in the article's Creative Commons licence and your intended use is not permitted by statutory regulation or exceeds the permitted use, you will need to obtain permission directly from the copyright holder. To view a copy of this licence, visit http://creativecommons.org/licen ses/by/4.0/.

\section{References}

Andersson M, Larsson JP (2016) Local entrepreneurship clusters in cities. J Econ Geograph 16(1):39-66 Anjomani A (2002) Regional growth and interstate migration. Socioecon Plann Sci 36(4):239-265

Attanasio OP, Weber G (2010) Consumption and saving: Models of intertemporal allocation and their implications for public policy. J Econ Lit 48(3):693-751

Baum-Snow N, Hartley, DA, Lee KO (2019) The long-run effects of neighborhood change on incumbent families. Retrieved from https://www.chicagofed.org/ /media/publications/working-papers/2019/ wp2019-02-pdf.pdf

Ben-Shalom Y, Moffitt R, Scholz JK (2012) An assessment of the effectiveness of antipoverty programs in the United States. In: Jefferson P (ed) The Oxford handbook of the economics of poverty. Oxford University Press, New York, NY, pp 709-749

Berner E, Gomez G, Knorringa P (2012) 'Helping a large number of people become a little less poor': The logic of survival entrepreneurs. Eur J Dev Res 24(3):382-396

Bertrand M, Duflo E, Mullainathan S (2004) How much should we trust differences-in-differences estimates? Quart J Econ 119(1):249-275

Bitler MP, Gelbach JB, Hoynes HW (2006) What mean impacts miss: Distributional effects of welfare reform experiments. Am Econ Rev 96(4):988-1012

Blanchflower DG (2000) Self-employment in OECD countries. Labour Econ 7(5):471-505

Block J, Sandner P (2009) Necessity and opportunity entrepreneurs and their duration in self-employment: Evidence from German micro data. J Ind Compet Trade 9(2):117-137

Braymen C, Neymotin F (2014) Enclaves and entrepreneurial success. J Entrepreneur Public Policy 3(2):197-221

Buera FJ (2008) Persistency of poverty, financial frictions, and entrepreneurship. Retrieved from http:// www.econ.ucla.edu/fjbuera/papers/paper120071217.pdf

Caldwell SB, Clarke GP, Keister LA (1998) Modelling regional changes in US household income and wealth: A research agenda. Eviron Plann C Gov Policy 16(6):707-722

Cameron AC, Miller DL (2015) A practitioner's guide to cluster-robust inference. J Human Resource 50(2):317-372

Capello R, Nijkamp P (2019) Handbook of regional growth and development theories: Edward Elgar Publishing

Chakravarty S, Shahriar AZM (2015) Selection of borrowing partners in joint liability-based microcredit: Evidence from framed field experiments in Bangladesh. Entrep Theory Pract 39(1):129-144

Chaudry A, Wimer C, Macartney S, Frohlich L, Campbell C, Swenson K, Hauan S (2016) Poverty in the United States: 50-year trends and safety net impacts. US Department of Health and Human Services, Washington, DC 
Chen M (2005) Rethinking the informal economy: Linkages with the formal economy and the formal regulatory environment. Retrieved from https://www.wider.unu.edu/sites/default/files/rp200510.pdf

Chinitz B (1961) Contrasts in agglomeration: New york and pittsburgh. Am Econ Rev 51(2):279-289

Chivers D (2017) Success, survive or escape? Aspirations and poverty traps. J Econ Behav Organ 143(1):116-132

Crettaz E, Suter C (2013) The impact of adaptive preferences on subjective indicators: An analysis of poverty indicators. Soc Indic Res 114(1):139-152

Cumming D, Johan S, Uzuegbunam I (2020) An anatomy of entrepreneurial pursuits in relation to poverty. Entrep Reg Dev 32(1-2):21-40

Dalton PS, Ghosal S, Mani A (2016) Poverty and aspirations failure. Economic J 126(590):165-188

Datta PB, Gailey R (2012) Empowering women through social entrepreneurship: Case study of a women's cooperative in India. Entrep Theory Pract 36(3):569-587

De Beer M (2018) Local social value creation by neighborhood-based entrepreneurs. Soc Enterp J 14(4):450-469

Devereux S (2002) Can social safety nets reduce chronic poverty? Develop Policy Rev 20(5):657-675

Dickert S, Houser S, Scholz JK (1995) The earned income tax credit and transfer programs: A study of labor market and program participation. Tax Policy Econ 9(1):1-50

Eissa N, Hoynes HW (2004) Taxes and the labor market participation of married couples: The earned income tax credit. J Public Econ 88(9-10):1931-1958

Eissa N, Hoynes HW (2006) Behavioral responses to taxes: Lessons from the EITC and labor supply. Tax Policy and the Economy 20(1):73-110

Ellwood DT (2000) The impact of the earned income tax credit and social policy reforms on work, marriage, and living arrangements. Nat Tax J 53(4):1063-1105

Estrin S, Mickiewicz T (2012) Shadow economy and entrepreneurial entry. Rev Dev Econ 16(4):559-578

Falco P, Haywood L (2016) Entrepreneurship versus joblessness: Explaining the rise in self-employment. J Dev Econ 118(1):245-265

Field E, Pande R, Papp J, Rigol N (2013) Does the classic microfinance model discourage entrepreneurship among the poor? Experimental evidence from India. Am Econ Rev 103(6):2196-2226

Fields, GS (2019) Self-employment and poverty in developing countries. Retrieved from https://wol.iza. org/articles/self-employment-and-poverty-in-developing-countries/long

Fischer MM, Nijkamp P (2019) The nexus of entrepreneurship and regional development. In: Capello A, Nijkamp P (eds.) Handbook of regional Growth growth and development theories: Revised and extended, 2nd edn. Edward Elgar Publishing, pp 198-217

Freire-Gibb LC, Nielsen K (2014) Entrepreneurship within urban and rural areas: Creative people and social networks. Reg Stud 48(1):139-153

Friedlander D, Robins PK (1997) The distributional impacts of social programs. Eval Rev 21(5):531-553

Fryer Jr RG (2017) The production of human capital in developed countries: Evidence from 196 randomized field experiments. In: Handbook of Economic Field Experiments, vol. 2(1). Elsevier, pp 95-322

Genicot G, Ray D (2020) Aspirations and economic behavior. Ann Rev Econ 12:715-746

Gennetian LA, Wolf S, Hill HD, Morris PA (2015) Intrayear household income dynamics and adolescent school behavior. Demogr 52(2):455-483

GeoLytics, I. (2016) Neighborhood change database, tract data from 1970-2010: Author Somerville, NJ.

Ghani E, Kerr WR, O'Connell SD (2014) Political reservations and women's entrepreneurship in India. J Dev Econ 108(1):138-153

Gittell R, Thompson JP (1999) Inner-city business development and entrepreneurship: New frontiers for policy and research. In: Ferguson F, Dickens WT (eds) Urban problems and community development. Brookings Institution Press, pp 473-520

Gómez GM, Chawla S, Fransen J (2020) Exploring the entrepreneurial ecosystem within the informal economy with a multifactor framework. In: Urban studies and entrepreneurship. Springer, pp $181-202$

Grogger J (2003) The effects of time limits, the EITC, and other policy changes on welfare use, work, and income among female-headed families. Rev Econ Stat 85(2):394-408

Hahn H, Kuehn D, Hassani H, Edin K (2019) Relief from government-owed child support debt and its effects on parents and children. Retrieved from https://www.urban.org/sites/default/files/publication/100812/relief_from_government-owed_child_support_debt_and_its_effects_on_parents_and_ children_4.pdf 
Hamilton L (2016) Incentives in the temporary assistance for needy families program: A review of the literature. Poverty \& Public Policy 8(2):141-149

Hanson K (2010) Food Assistance National Input Output Multiplier (FANIOM) Model and stimulus effects of SNAP. Diane Publishing

Hayek FA (1945) The use of knowledge in society. Am Econ Rev 35(4):519-530

Henrekson M, Sanandaji T (2020) Measuring entrepreneurship: Do established metrics capture Schumpeterian entrepreneurship? Entrep Theory Pract 44(4):733-760

Hill HD, Morris P, Gennetian LA, Wolf S, Tubbs C (2013) The consequences of income instability for children's well-being. Child Dev Perspect 7(2):85-90

Hoogendoorn B (2016) The prevalence and determinants of social entrepreneurship at the macro level. J Small Bus Manage 54(1):278-296

Iftikhar MN, Justice JB, Audretsch DB (2020) Introduction: Cities and entrepreneurship. In: Iftikhar MN, Justice JB, Audretsch DB (eds) Urban studies and entrepreneurship. Springer International Publishing, Cham, pp 1-16

Karlsson C, Dahlberg R (2003) Entrepreneurship, firm growth and regional development in the new economic geography: Introduction. Small Bus Econ 21(2):73-76

Kleinhans R, Reuschke D, van Ham M, Mason C, Syrett S (2017) Entrepreneurial Neighbourhoods. Edward Elgar Publishing

Kobeissi N (2010) Gender factors and female entrepreneurship: International evidence and policy implications. J Int Entrep 8(1):1-35

Koellinger P, Minniti M (2009) Unemployment benefits crowd out nascent entrepreneurial activity. Econ Lett 103(2):96-98

Kwon I, Sohn K (2021) Trust or distrust: Entrepreneurs vs. self-employed. Small Bus Econ 56(4):1553-1570

Laird J, Parolin Z, Waldfogel J, Wimer C (2018) Poor state, rich state: Understanding the variability of poverty rates across US states. Sociol Sci 5(1):628-652

Leonard M (1998) Invisible Work, Invisible Workers: The informal economy in Europe and the US. Springer

Levitte Y (2004) Bonding social capital in entrepreneurial developing communities-survival networks or barriers? Community Dev 35(1):44-64

Liang J, Goetz SJ (2016) Self-employment and trade shock mitigation. Small Bus Econ 46(1):45-56

Lobao L, Hooks G (2003) Public employment, welfare transfers, and economic well-being across local populations: Does a lean and mean government benefit the masses? Soc Forces 82(2):519-556

Mair J, Marti I, Ventresca MJ (2012) Building inclusive markets in rural Bangladesh: How intermediaries work institutional voids. Acad Manag J 55(4):819-850

Mariani M, Mattei A, Storchi L, Vignoli D (2019) The ambiguous effects of public assistance to youth and female start-ups between job creation and entrepreneurship enhancement. Scienze Regionali 18(2):237-260

Marlow S (1997) Self-employed women-new opportunities, old challenges? Entrep Reg Dev 9(3):199-210

Martin BC, McNally JJ, Kay MJ (2013) Examining the formation of human capital in entrepreneurship: A meta-analysis of entrepreneurship education outcomes. J Bus Ventur 28(2):211-224

Michálek A, Výboštok J (2019) Economic growth, inequality and poverty in the EU. Soc Indic Res 141(2):611-630

Moffitt RA (1999) Demographic change and public assistance expenditures. Retrieved from https:// www.nber.org/papers/w6995

Moffitt RA (2015) The deserving poor, the family, and the US welfare system. Demogr 52(3):729-749

Morduch J (2000) The microfinance schism. World Dev 28(4):617-629

Morello, C. (2010). About 44 million in US lived below poverty line in 2009, census data show. Retrieved from: http://people.uncw.edu/imperialm/UNCW/PLS_505/Wash_Post_rising-pover ty_rate_9_16_10.pdf.

Morris MH (2021) Poverty and entrepreneurship in developed economies. In: World Encyclopedia of Entrepreneurship. Edward Elgar Publishing

Morris MH, Tucker R (2021) The entrepreneurial mindset and poverty. J Small Buss Manag. https:// doi.org/10.1080/00472778.2021.1890096

Morris MH, Santos SC, Neumeyer X (2018) Poverty and Entrepreneurship in Developed Economies. Edward Elgar Publishing 
Morris MH, Kuratko DF, Audretsch DB, Santos S (2020a) Overcoming the liability of poorness: Disadvantage, fragility, and the poverty entrepreneur. Small Bus Econ. https://doi.org/10.1007/ s11187-020-00409-w

Morris MH, Santos SC, Neumeyer X (2020b) Entrepreneurship as a solution to poverty in developed economies. Bus Horiz 63(3):377-390

Neumark D, Young T (2019) Enterprise zones, poverty, and labor market outcomes: Resolving conflicting evidence. Reg Sci Urban Econ 78(1):103462

Neumark D, Asquith B, Bass B (2019) Longer-run effects of anti-poverty policies on disadvantaged neighborhoods. Contemp Econ Policy. https://doi.org/10.1111/coep.12445

Notten G, De Neubourg C (2011) Monitoring absolute and relative poverty:"Not enough" is not the same as "much less." Rev Inc Wealth 57(2):247-269

Olds GE (2014) Entrepreneurship and the Social Safety Net. Retrieved from https://www.semanticsc holar.org/paper/Entrepreneurship-and-the-Social-Safety-Net-Olds/a78ff618c5b9acd555987e1bf $892871 \mathrm{f} 8 \mathrm{a} 86 \mathrm{ee} 48$

Olsen, W. (2010). Poverty as a malaise of development: A discourse analysis in its global context'. In A. P. M. o. d. Boran (Ed.), Poverty: Malaise of Development (Vol. 6, pp. 33-65): Chester Academic Press.

Oreopoulos P (2003) The long-run consequences of living in a poor neighborhood. Quart J Econ 118(4):1533-1575

Plummer LA (2010) Spatial dependence in entrepreneurship research: Challenges and methods. Organ Res Methods 13(1):146-175

Portes A, Manning RD (2005) The immigrant enclave: Theory and empirical examples. The Urban Sociology Reader 38:583-594

Proctor BD, Semega JL, Kollar MA (2016) Income and poverty in the United States: 2015. Retrieved from https://www.census.gov/data/tables/2016/demo/income-poverty/p60-256.html.P60-256

Ray D (2006) Aspirations, poverty, and economic change. In Banerjee AV, Bénabou R, Mookherjee D (eds) Understanding poverty. vol 1. Oxford University Press, pp 409-421

Reynolds PD (2002) Global entrepreneurship monitor GEM 2001 summary report. Retrieved from https://www.gemconsortium.org/report/gem-2001-global-report

Rhodes RE, Brown SG, McIntyre CA (2006) Integrating the perceived neighborhood environment and the theory of planned behavior when predicting walking in a Canadian adult sample. Am J Health Promot 21(2):110-118

Rodriguez E (2001) Keeping the unemployed healthy: The effect of means-tested and entitlement benefits in Britain, Germany, and the United States. Am J Public Health 91(9):1403-1411

Sandberg J (2016) Between poor relief and human capital investments-paradoxes in hybrid social assistance. Soc Policy Administrat 50(3):316-335

Schreiner M (1999) Self-employment, microenterprise, and the poorest Americans. Soc Service Rev 73(4):496-523

Scott L, Dolan C, Johnstone-Louis M, Sugden K, Wu M (2012) Enterprise and inequality: A study of Avon in South Africa. Entrep Theory Pract 36(3):543-568

Shane S (2009) Why encouraging more people to become entrepreneurs is bad public policy. Small Bus Econ 33(2):141-149

Small ML, McDermott M (2006) The presence of organizational resources in poor urban neighborhoods: An analysis of average and contextual effects. Soc Forces 84(3):1697-1724

Sorenson O (2017) Regional ecologies of entrepreneurship. J Econ Geograph 17(5):959-974

Stolzenberg RM, Tienda M (1997) English proficiency, education, and the conditional economic assimilation of Hispanic and Asian origin men. Soc Sci Res 26(1):25-51

Stough RR (2016) Entrepreneurship and regional economic development: Some reflections. Journal of Regional Research 36(1):129-150

Sutter C, Bruton GD, Chen J (2019) Entrepreneurship as a solution to extreme poverty: A review and future research directions. J Bus Ventur 34(1):197-214

Sutton SA (2010) Rethinking commercial revitalization: A neighborhood small business perspective. Econ Dev Q 24(4):352-371

Thornton PH, Ocasio W, Lounsbury M (2015) The institutional logics perspective. In: Scott RA, Kosslyn SM (eds) Emerging trends in the social and behavioral sciences: an interdisciplinary, searchable, and linkable resource. Wiley, pp 1-22

Thurik AR, Carree MA, Van Stel A, Audretsch DB (2008) Does self-employment reduce unemployment? J Bus Ventur 23(6):673-686 
Tsvetkova A, Partridge M, Betz M (2019) Self-employment effects on regional growth: A bigger bang for a buck? Small Bus Econ 52(1):27-45

Urbano D, Aparicio S (2016) Entrepreneurship capital types and economic growth: International evidence. Technol Forecast Soc Chang 102:34-44

US Census. (2014). Census Tracts [https://www2.census.gov/geo/pdfs/education/CensusTracts.pdf] o. Document Number)

US Census Bureau. (2020). Glossary available at https:/www.census.gov/programs-surveys/geography/ about/glossary.html\#par_textimage_13 [accessed on June 25, 2020].

Van Stel A, Van der Zwan P (2020) Analyzing the changing education distributions of solo self-employed workers and employer entrepreneurs in Europe. Small Bus Econ 55(2):429-445

Venugopal S, Viswanathan M, Jung K (2015) Consumption constraints and entrepreneurial intentions in subsistence marketplaces. J Public Policy Mark 34(2):235-251

Williams CC (2014) Out of the shadows: A classification of economies by the size and character of their informal sector. Work Employ Soc 28(5):735-753

Williams CC, Windebank J (2002) The uneven geographies of informal economic activities: a case study of two British cities. Work Employ Soc 16(2):231-250

Wilson C, Wilson P (2017) Make poverty business: Increase profits and reduce risks by engaging with the poor. Routledge

Yeung HW-C (2009) Transnationalizing entrepreneurship: A critical agenda for economic geography. Prog Hum Geogr 33(2):210-235

Ziliak JP, Hardy B, Bollinger C (2011) Earnings volatility in America: Evidence from matched CPS. Labour Econ 18(6):742-754

Publisher's note Springer Nature remains neutral with regard to jurisdictional claims in published maps and institutional affiliations. 